\title{
Doença mental e os estranhos personagens da literatura infantil ${ }^{*}$
}

\author{
Rogerio F. Guerra \\ Universidade Federal de Santa Catarina
}

Os contos de fadas e as histórias populares revelam a estrutura social, superstições e o comportamento do homem antigo. Esse material pode ser útil para a compreensão do sistema legal e conflito parental (orfandade, negligência e abuso infantil perpetrado pelas madrastas), assim como ele revela o status social das esposas e das crianças na família patriarcal. Fadas, bruxas e personagens como Rapunzel e Chapeuzinho Vermelho indicam um viés feminil, mas as garotas e mulheres jovens eram susceptíveis a sérios abusos, principalmente negligência parental, abandono e casamento precoce (efeito Cinderela). O artigo examina as doenças mentais e distúrbios comportamentais (e.g., esquizofrenia, alcoolismo, mal de Parkinson e perturbações do sono) exibidos pelos personagens dos contos de fadas e literatura popular.

Palavras-chave: Literatura popular - Contos de fadas - Abuso infantil - Orfandade Efeito cinderela - Doença mental.
Fairy tales and popular folk stories reveal the social structure, superstitions and the behavior of the ancient people. Such material may be useful to understanding the law system and parental conflict (orphanhood, negligence and child abuse by stepmother), as well reveals the status of wives and children in patriarchal families. Fairies, witches and characters as Rapunzel and Little Red Riding Hood indicated a feminine bias, but it has been noted that girls and young women suffer serious abuse in tales, mainly parental negligence, abandon and precocious marriage (Cinderella effect). In this article, it has been described the mental diseases and some behavioural disturbances (e.g., schizophrenia, alcoholism, Parkinsonism and sleep disorders) exhibited by characters of fairy tales and popular literature.

Keywords: Popular literature - Fairy tales Child abuse - Orphanhood - Cinderella effect - Mental disease.

\section{Introdução}

A literatura infantil revela aspectos "fossilizados" da sociedade patriarcal e $A$ as crenças e superstições do homem antigo. As crianças se encantam com o desfecho das histórias (a prevalência do "bem" o sobre o "mal"), mas os olhos atentos de um adulto também enxergam a instabilidade familiar, a luta constante pela ração diária, preocupações com as doenças oportunísticas e o temor do homem em relação aos elementos da natureza (animais, florestas e lugares ermos).

\footnotetext{
* Mental disease and the curious characters of the fairy tales

${ }^{1}$ Professor-Titular do Departamento de Psicologia, Centro de Filosofia e Ciências Humanas, UFSC. Editor da Revista de Ciências Humanas. Endereço para correspondências: Universidade Federal de Santa Catarina, Departamento de Psicologia, Campus Universitário, Florianópolis, SC, 88040-900 (rfguerra@cfh.ufsc.br).
} 
As histórias misturam elementos da mitologia, religiosidade e do folclore medieval. Embora parecidas umas com as outras, elas contêm informações preciosas sobre um mundo desaparecido.

Muitos vêem esse tipo de literatura como algo pueril, mas muitos autores de histórias infantis foram intelectuais respeitáveis. Charles Perrault (16281703) foi membro da Academia Francesa e atuou como conselheiro de Luís XV. A sua coletânea Contes de ma mère l'oye (1697) foi um marco na literatura infantil; o conto Les fées (As fadas) foi a origem da expressão "contos de fadas". O dinamarquês H.C. Andersen (1805-75) foi escritor bastante reverenciado e suas histórias tornaram inesquecíveis personagens como o Patinho Feio, o Soldadinho de Chumbo e Ariel, a sereiazinha apaixonada. Os irmãos Jacob (1785-1863) e Wilhelm Grimm (1786-1859) foram especialistas em filologia, mas são mundialmente conhecidos pela coletânea Kinder und Hausmärchen (1812-22). Ambos foram professores na Universidade de Göttingen e Jacob Grimm foi autor de uma das mais importantes obras de sua especialidade (Deutsche Grammatik, 1819) - o seu nome foi imortalizado num epônimo, a lei de Grimm.

As histórias infantis servem para transmitir ensinamentos éticos e morais e proporcionam às crianças uma forma de compreensão do mundo (BETTELHEIM, 1975; ALEXANDER et al., 2001). Prevalece a crença em Deus e nos valores morais, pois no final o bem prevalece sobre o mal. As Histórias de proveito e exemplo de Gonçalo Fernandes Trancoso (c.1515-96) exemplificam bem essa peculiaridade. A obra é um tesouro literário que descreve Portugal do século 16, quando o país se encontrava flagelado pela peste (1569). Conta-se que Trancoso perdera vários familiares (a esposa, uma filha de 24 anos, um filho e um neto) e escrevera seus contos para "desalivar" (aliviar) os tormentos da imaginação.

Muitos críticos viam com desdém a obra de Trancoso, pois ele tinha um estilo peculiar e usava expressões um tanto redundantes, como "fisiognomia do rosto", "bracejando com os braços" e "em tão pobre traje e tão mal enroupado". Entretanto, era dessa forma que as pessoas comuns falavam e a análise do estilo rebuscado é útil para uma compreensão da evolução da estrutura e vocabulário do idioma português. Os dicionários atuais explicam que a expressão "histórias de Trancoso" geralmente é utilizada para designar algo inventado, fantasioso, falso ou incrível (märchen), mas a explicação não condiz com as descrições precisas e detalhadas que Trancoso fazia sobre os conflitos de interesses e como os julgamentos se realizavam nos tribunais. Os apressados podem imaginar que este tipo de literatura não tem serventia além do puro entretenimento, mas um scholar esclareceu o equívoco: 
Trancoso trata esses assuntos com minúcia, precisão, propriedade nos termos, e até, visivelmente, com amor de verdadeiro profissional, comprazendo-se em citar os dizeres textuais das sentenças e dos testamentos, o que torna o seu livro de precioso ensinamento para os jurisconsultos que pretendam conhecer a tecnologia jurídica vernácula do século XVI, tanto mais que as obras magistrais de Direito eram nessa época geralmente escritas em latim(DE CAMPOS, 1921; p. xv).

Portugal e Brasil ocupam uma honrosa posição no cenário da literatura infantil, pois Trancoso deixou uma legião de ilustres seguidores, como Teófilo Braga (1843-1924), Adolfo Coelho (1847-1919) e Consiglieri Pedroso (1851-1910). Todos esses autores foram representantes da tradição portuguesa. No cenário brasileiro surgem as coletâneas de Silvio Romero (1851-1914) e Câmara Cascudo (1898-1986). Os contos portugueses e brasileiros são, em sua maioria, homólogos aos contos clássicos de Perrault e dos irmãos Grimm, mas eles mostram alguns detalhes que só podem ser explicados em função da nossa herança cultural. Com efeito, os personagens interagem com mouros, turcos e negros (descritos de modo negativo) e, em certas circunstâncias, S. Pedro, a Virgem Maria ou Nosso Senhor (Jesus ou próprio Deus) descem dos céus em socorro aos percalços de seus protegidos. Os personagens da cristandade atuam em substituição às fadas.

\section{Charme, fascinação e glamour}

A coletânea dos irmãos Grimm se transformou em sinônimo de "contos de fadas", mas a palavra märchen serve para designar uma narrativa popular ou tradicional, enquanto que "contos de fadas" envolvem, é claro, as fadas e seus poderes mágicos (ver FÜRSTENHEIM, 1951). No Brasil, além dessa terminologia, as pessoas usam as expressões "histórias da carochinha", "histórias do arco da velha ou" "histórias de Trancoso" como sinônimos de literatura infantil. Essas historietas eram lidas em sistema comunal no ambiente doméstico e, portanto, não serviam apenas para entreter as crianças - lembremos que o analfabetismo era comum, os lares eram pouco iluminados e as divagações intelectuais não combinavam com as duras lides diárias. Isso explica os enredos curtos e repetitivos, bem como certa sensualidade no relacionamento entre os personagens.

Fadas ou parcas são personagens da mitologia grega. Elas formavam um trio composto por Cloto, Laquesis e Átropos; viviam num palácio nas regiões olímpicas e se encarregavam do destino de cada ser humano, o qual estava definitivamente gravado numa placa de ferro ou bronze. Cloto tinha o controle do fio da vida; ela é a mais jovem das três e seu nome significa "fiandeira". 
Laquesis era quem se encarregava de pôr o fio da vida no fuso; o seu nome significa "sorte" ou a ação de "tirar a sorte". Átropos é a mais velha das três e é quem controla o tamanho do fio da vida, cortando-o no exato momento; o seu nome significa "inflexível" e deu origem ao fármaco atropina. As fadas eram mulheres velhas e severas e que nada faziam em benefício do ser humano. Originalmente, elas eram vistas como simples bruxas e fatae é a origem etimológica dos vocábulos fado (profecia ou destino), fatal, fatídico e fatalidade. Entretanto, a ação do tempo deu surgimento a uma interessante adulteração semântica: as fadas se transformaram em mulheres jovens e bondosas e inspiraram a designação "contos de fadas".

Outra adulteração semântica ocorreu com as palavras fascinação e glamour, propriedades inerentes às bruxas. A primeira é derivada de fascinum ou fascinare, palavras em Latim que designavam os feitiços lançados pelas bruxas através do olhar (mau olhado ou mal de l'occhio). Por outro lado, glamour é corruptela de glomerie ou glamer, a origem latina de grammar (inglês) e gramática (português). Eruditos e membros dos tribunais conversavam numa linguagem ininteligível ao homem comum, tal como os sussurros estranhos que as bruxas emitiam ao pé do ouvido de um bebê, visando interferir negativamente em seu futuro. Outra palavra decorrente do vocabulário das bruxas é charme (carmen ou carminis, Latim), atualmente utilizada para designar os encantos de uma pessoa, especialmente das mulheres. Originalmente, ela era uma referência às formulas mágicas, capacidade de encantamento ou servia para designar os amuletos utilizados pelas bruxas.

As bruxas conheciam os efeitos das ervas e às vezes usavam suas habilidades para o tratamento de doenças variadas (e.g., dor de barriga, mau olhado e quebranto). Elas também atendiam as gestantes em momentos de apuro e eram as primeiras pessoas que tinham contato com o bebê, antes da própria mãe. Em razão disso, as gestantes temiam as parteiras, pois elas podiam se aproveitar desse privilégio para sussurrar um glamour no ouvido do recém-nascido, deixando-o permanentemente fadado. Fadas, fascinação e glamour servem para designar as mulheres de beleza excepcional ou são equivalentes aos encantos femininos, mas essas palavras originalmente significavam o oposto daquilo que imaginamos.

Muitas histórias européias foram transportadas para os trópicos e o transporte originou alguns erros de tradução, como a vestimenta de Chapeuzinho Vermelho (era um capelinho, espécie de capa com capuz que os viajantes usavam durante os longos percursos) e o curioso sapatinho de cristal de Cinderela. O modelo original era mais confortável e mais de acordo com a estética feminina: contase que se tratava de pantoufles em vair (sapatos de pele de arminho branco). 
A palavra vair caíra em desuso no século 14 e Charles Perrault (1628-1703) não conhecia o seu significado, mas entendeu que se tratava de algo equivalente à verre (vidro comum, em francês). $\mathrm{O}$ resultado final: arminho branco se transformou em vidro, o vidro em cristal.

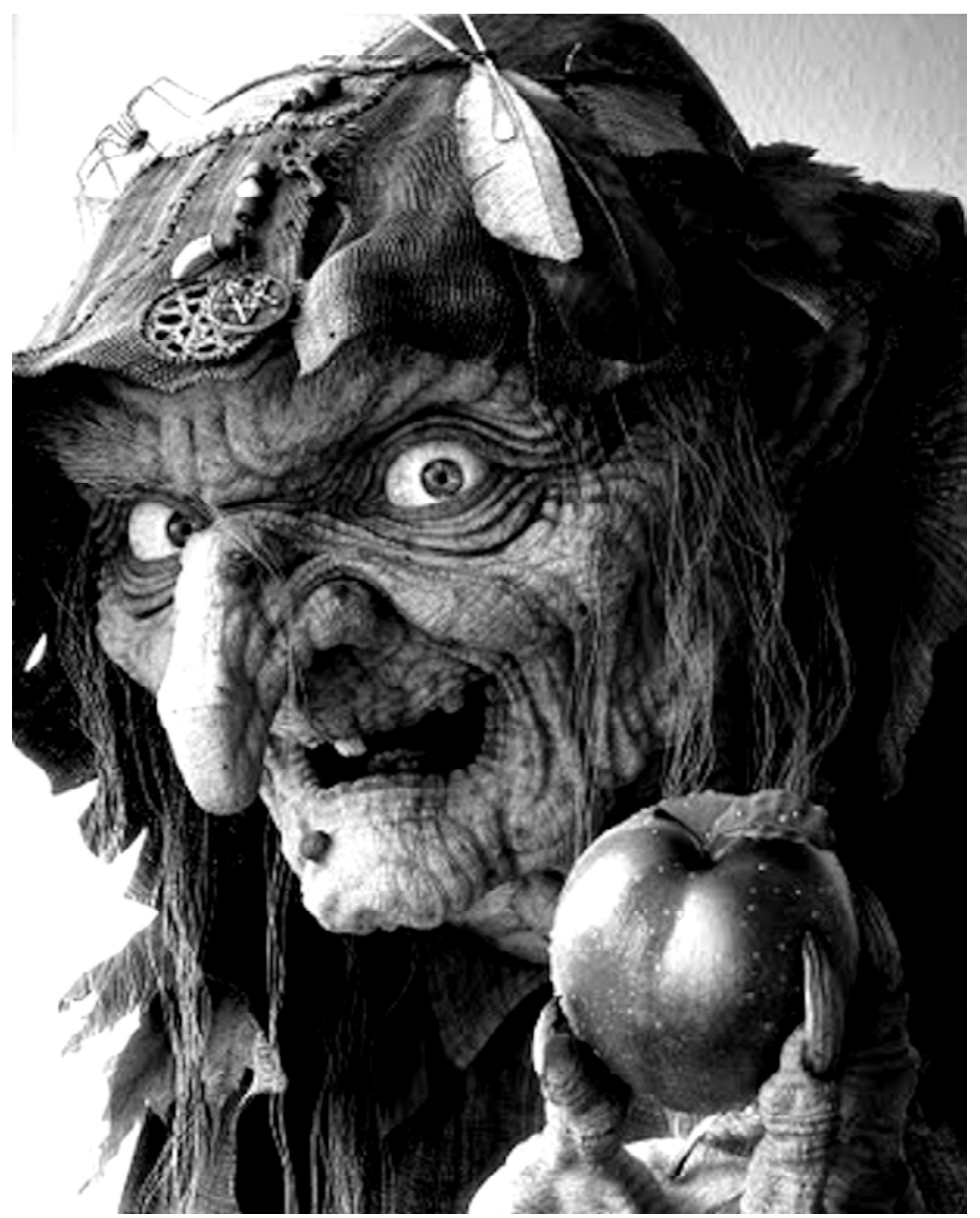

Figura 1

A bruxa malvada, mulher idosa que muito provavelmente padecia de alguma enfermidade mental. 


\section{HüMANAS}

No Brasil, os contos de fadas também são conhecidos como "histórias da carochinha". Do ponto de vista etimológico, carocha era uma espécie de mitra feita de papelão que os condenados pela Inquisição punham na cabeça, antes de serem levados à fogueira. Arco da velha é mais ou menos sinônimo de arco íris. O conceito está relacionado ao fantástico e inverossímil, como a crença de que a pessoa muda de sexo caso atravesse um arco íris. O uso corriqueiro das expressões contos de fadas e histórias da carochinha proporcionou um significado positivo e sentimental, mas fadas e carochas eram mulheres devotadas ao mal que tinham especial ligação com o Diabo.

No imaginário popular, mulheres idosas representam o mal, a escuridão e o crepúsculo da vida. Carochas eram mulheres excêntricas ou meio caducas que viviam isoladas em florestas. Elas detinham conhecimentos sobre ervas, falavam com os animais e lançavam sortilégios variados; eram simples bruxas. As ilustrações e os enredos das historietas revelam claramente que elas exibiam sinais da velhice, como o andar encurvado, miopia, pele enrugada e alongamento do tecido cartilaginoso do nariz e orelhas. Além desses problemas físicos, as bruxas eram segregadas do convívio social, falavam sozinhas, tinham êxtases mediúnicos ou até convulsões, indicando que elas padeciam de enfermidades mentais variadas (e.g., esquizofrenia, epilepsia ou distúrbio bipolar).

O comportamento bizarro e extravagante das bruxas talvez fosse resultante de intoxicação alimentar, ocasionada pelo consumo de pão de centeio contaminado pelo fungo ergot (Claviceps purpurea). O pão era um alimento importante na dieta do homem antigo, como podemos notar em muitas expressões populares e descrições do Novo Testamento, e as infestações do fungo eram comuns nas plantações de centeio. O ergotismo também era conhecido como "fogo de Santo Antonio" ou "dança de São Vito". Alguns estudos apontam que a caça às bruxas de Salem (1692), episódio que levou 19 adolescentes "endemoninhadas" à morte na forca, nada mais era que o resultado do consumo de pão de centeio contaminado; o ergotismo praticamente desapareceu do catálogo nosológico. Os sintomas da enfermidade são alucinações, espasmos e tremores do corpo; a intoxicação também era a origem das isquemias e gangrenas nas extremidades do corpo, como foi bem documentado em alguns estudos sobre história da medicina (CHRISTOPOULOS et al. 2001; De COSTA, 2002; WALLER, 2009).

O cenário dos contos de fadas

As histórias infantis nem sempre se passam num cenário idílico ou têm desenlace feliz. Em Menino de engenho (1932), o escritor José Lins do Rego (1901-57) faz um relato triste e nostálgico sobre a infância no meio rural e, 
ao mesmo tempo, ressalta a importância das velhas senhoras na educação das crianças; elas perambulavam pela região e eram ansiosamente aguardadas pelos molecotes dos engenhos. O livro é triste do começo ao fim. Ele descreve a infância e os rituais de ingresso na vida adulta de Carlinhos, o menino que muito cedo enfrentara o assassinato da mãe (uxoricídio) e a internação do pai assassino numa instituição para doentes mentais.

Após uma série de infortúnios, a criança é enviada à fazenda do avô materno, onde ele se depara com um mundo fascinante e cheio de acontecimentos interessantes. Num certo momento, Carlinhos descobre numa capela da fazenda a imagem do menino Jesus. Os olhos azuis, o sorriso nos lábios e a postura solene do Cristo menino atraem suas atenções. Curioso em saber o que encontrava por baixo do manto azul, ele avança nas explorações e nota a existência de uma rolinha bicuda por baixo das vestes do santo menino. Carlinhos fica espantado com a descoberta, pois a sua pequena cabeça não concebia que os habitantes do céu tivessem necessidade de possuir o equipamento anatômico.

A obra também descreve a iniciação sexual dos moleques que viviam nos engenhos, inicialmente com os semoventes (cabras e vacas: "hoje vamos fazer porcaria no curral"; DO REGO, 2003; p. 65). O bestialismo verdadeiro ocorre mais freqüentemente no meio rural, envolvendo um homem jovem e um animal fêmeo (caprinos, bovinos e eqüinos), mas também ocorrem variações nos papéis - i.e., homem com animal macho, o qual the serve como fêmea ou ele próprio se presta a tal papel diante de um macho. As mulheres raramente se envolvem em tais práticas, mas a indústria pornográfica (revistas, filmes e sites na Internet) explora a atração por cenas bizarras, as quais mostram belas atrizes sendo lambidas por cães ou manipulando os órgãos genitais de cavalos.

O bestialismo é uma prática mais restrita ao universo dos meninos ou dos homens jovens com baixo discernimento intelectual ou cognitivo. No primeiro caso, trata-se de um fenômeno efêmero e circunstancial e, portanto, não indica necessariamente algum problema mental ou a degradação dos costumes. A busca de prazer erótico ou sexual através de intercursos com animais também é conhecida como zoofilia, embora a palavra seja mais adequada para designar o "amor aos animais". A prática tem duas variações: zooerastia e formicofilia. A primeira designação é uma referência à tentativa de realizar intercurso sexual com animais domésticos (cabras, vacas ou éguas). Por outro lado, formicofilia é a tentativa de obtenção de satisfação sexual através da locomoção, comportamento exploratório e picadas realizadas por animais de pequeno porte (formigas, aranhas, lesmas ou pererecas, por exemplo) sobre certas partes do corpo de uma pessoa (genitália, seios e anus, principalmente). 


\section{HüAnas}

Algo parecido à formicofilia foi descrito por Jonathan Swift (As viagens de Gulliver, 1726). Ao visitar o reino de Brobdingnag, habitado por gigantes, o herói sofre os abusos praticados pelas damas. Elas despiam o minúsculo Gulliver, trancavam-se em suas alcovas e se divertiam deixando-o escalar suas mamas desnudas. A mais linda e a mais travessa dessas damas tinha apenas dezesseis anos, mas tinha prazer especial em forçar o herói a escalar o bico de suas mamas. O curioso nessas obras é o fato de que elas descrevem o universo infantil ou foram elaboradas para o deleite das crianças.

Os intercursos sexuais com os animais são potencialmente perigosos, em razão de traumatismos, perfurações de órgãos internos e contaminações por agentes patogênicos desconhecidos. $\mathrm{O}$ tema pertence ao rol das parafilias e desperta cada vez mais as atenções dos especialistas em medicina forense. Ao lado da necrofilia (i.e., atração sexual por cadáveres), o bestialismo é severamente condenado pela Bíblia (Lev 18:23, 20:15-16); a prática é considerada uma das doze maldições (Dt 27:21) e é descrita na seção Santidade dos sexos (Lev 18:1-30). O homem e a mulher que se entregavam aos prazeres bestiais, assim como o pobre animal que servia a tais propósitos, eram condenados à morte, pois se acreditava que os abomináveis consórcios carnais davam origem aos monstros (AGGRAWAL, 2009).

As bruxas eram severamente condenadas pelos tribunais da Santa Inquisição não somente pelo vínculo especial com Satã, mas em razão de seu relacionamento promíscuo com os animais, especialmente cães e gatos. A leitura da Bíblia revela que o bestialismo não era incomum, conforme podemos deduzir a partir das descrições acerca das extravagâncias sexuais das irmãs Oolá e Oolibá, ninfomaníacas que se prostituíam para saciar o calor do sexo. A mais jovem delas, Oolibá, era quem exibia maior apetite sexual - "E loucamente se apaixonou com o libidinoso apetite de dormir com aqueles, cujas carnes são como as carnes dos jumentos: e a destilação como a destilação dos cavalos" (Ez 23:20).

Voltaire tratou o bestialismo num tom irônico e mais divertido. A sua obra mais conhecida (Candide, 1759) dá vida ao ingênuo Cândido e ao Dr. Pangloss, aquele quem enxergava uma explicação racional para a natureza otimista do ser humano. Com efeito, o capítulo XVI descreve o momento em que Cândido e seu criado Cacambo descansam à sombra de uma árvore. Repentinamente, eles escutam gritos femininos e vêem duas mocinhas sendo perseguidas por dois macacos. Elas estavam inteiramente nuas e os animais perseguiam-nas, mordendo suas nádegas. Em razão da distância e da mistura dos sons, Cândido não conseguiu discernir se elas gritavam de pavor ou de satisfação. Por via das dúvidas, ele empunhou a sua espingarda e disparou dois tiros certeiros nos macacos. Feito isso, as mocinhas caíram em prantos e abraçaram ternamente os bichanos. Cândido ficou admirado com a "bondade natural" das donzelas, 
mas Cacombo mostrou-lhe a realidade das coisas: "- Fizestes uma obra-prima, caro mestre, mataste os dois amantes dessas jovens!". Cândido aprendera a manusear a arma com os búlgaros e era capaz de derrubar uma avelã, sem tocar nas folhas, mas a sua mente era incapaz de enxergar os fatos da vida. O seu criado the informa que os macacos preservam um quarto da humanidade e, portanto, é comum que eles ganhem as boas graças das damas.

A cópula com animais nem sempre está associada à busca do prazer, pois era uma fórmula secretamente recomendada aos homens que buscavam a cura para uma doença venérea. Essas moléstias eram muito freqüentes e arruinavam a saúde das pessoas, mas, curiosamente, os rapazotes tinham satisfação em exibir os sinais da "masculinidade" - Carlinhos, o personagem de Zelins do Rego, contraíra a doença por meio de um consórcio carnal com uma negra serviçal, aos 12 anos de idade, e andava com as pernas arreganhadas para todos saberem que ele já era um macho de verdade!

A iniciação sexual das crianças sertanejas geralmente se dava com animais, mas elas também recorriam às bananeiras, melancias e frutas dos mandacarus! (FREYRE, 1999). Não existia tratamento eficaz para as doenças venéreas, de modo que as pessoas recorriam às rezas, benzeduras ou procedimentos bizarros. Com efeito, os antigos acreditavam que o intercurso sexual com uma mulher virgem era o procedimento mais eficaz para livrar o homem de uma doença venérea, mas o bestialismo também era uma fórmula secretamente recomendada aos rapazes que padeciam de gonorréia ou sífilis, pois a moléstia era transferida ao animal fêmeo no momento do matrimonho (CASCUDO, 1988).

O homem antigo vivia bem próximo aos seus animais e às vezes compartilhava a moradia, o domus (origem da palavra "doméstico"), mas predominava a ingratidão ou insensibilidade em relação ao bem-estar dos animais que prestaram bons serviços nas fazendas. As historietas revelam que eles eram apenas instrumentos de trabalho (pet works) e só eram mantidos e alimentados enquanto tivessem utilidade. Quando perdiam serventia, os animais eram mortos ou eram abandonados à própria sorte, como pode ser visto em Os músicos viajantes (jumento), $O$ cão e o pardal (cão) e o Velho Sultão (cão), contos integrantes da coletânea dos irmãos Grimm. A historieta $A$ raposa e o cavalo se inicia com as seguintes palavras:

Um fazendeiro tinha um cavalo que fora seu fiel servidor. Entretanto, o pobre animal agora estava velho demais para trabalhar, então o fazendeiro já não the dava mais nada para comer, e um dia anunciou: Não cuidarei mais de ti, vai-te do meu estábulo. Não o aceitarei de volta enquanto não fores mais forte que um leão (Contos de Grimm, 2002; p. 203). 
As historietas infantis são fontes preciosas de informações, pois são registros congelados dos costumes. Elas descrevem as espécies da flora e da fauna, o vestuário dos personagens, os utensílios domésticos e o alimento servido à mesa. Os animais domésticos eram importantes para a sobrevivência do homem, mas predomina o sentimento utilitário em relação aos cavalos, cães e vacas. Entretanto, o tratamento despendido ao velho e alquebrado cavalo não é diferente do tratamento que os antigos senhores feudais despendiam aos escravos idosos ou enfermos, os quais eram abandonados à própria sorte.

O homem antigo vivia muito próximo aos animais domésticos, mas estes eram vistos apenas como um instrumento de trabalho ou eram estoques vivos de proteínas. O utilitarismo é algo bem visível nos contos de fadas, mas eventualmente emergem coisas interessantes. A coletânea dos irmãos Grimm (Grimm's fairy tales, 1996; Contos de Grimm, 2002) descreve o relacionamento de uma princesa com Falante, um cavalo que, como o nome indica, tinha capacidade de falar (A guardadora de gansos). Os enredos exibem um viés antropomórfico (i.e., atribuição de estados subjetivos e funções cognitivas humanas aos animais). Em outros casos, seres humanos assumem formas de um animal (licantropia), como bruxas que se transformam em lobos, raposas, corujas, corvos e morcegos; transformações involuntárias, ocasionadas por feitiços e encantamentos e atingiam mais os meninos e rapazes, como nas histórias $O$ príncipe sapo, Os sete corvos e $O$ zimbro (seres humanos transformados em sapo, corvo e num passarinho, respectivamente).

\section{Crianças, madrastas e teoria do investimento parental}

A literatura infantil é centrada no elemento feminino. A terminologia designativa (i.e., "contos de fadas" e "histórias da carochinha") e os personagens mais conhecidos (e.g., Branca de Neve, Pele de Asno e Ariel) também mostram este viés. Bruxas, madrastas e princesas são os personagens centrais, enquanto que os personagens masculinos são elementos secundários ou servem apenas para dar sustentação aos enredos. Os irmãos Grimm descrevem os cabelos, as feições e informa até a idade de Rapunzel (12 anos), mas pouco informa sobre o príncipe que ganhara o seu coração. Algo ainda mais interessante ocorre em "Branca de Neve e os sete anões", pois a historieta pouco informa sobre os pequeninos. O viés feminil pode ser explicado de várias formas, mas basicamente ele revela o mundo trágico das mulheres de outros tempos.

Os infortúnios vividos pelas mocinhas também espantam aqueles que examinam os contos de fadas com os olhos de um adulto. Elas casavam cedo, aos 12 ou 13 anos de idade, e eram "presenteadas" aos príncipes que batiam às portas das famílias miseráveis. A subserviência das mulheres e os anseios por um casamento são manifestações daquilo que as feministas conhecem como complexo de Cinderela. 
Os enredos eram amedrontadores, mas o final continha uma mensagem positiva: “... e viveram felizes para sempre". A vida real era bem diferente e os casamentos apressados só agravavam os infortúnios das mulheres. Com efeito, estudos sobre as taxas de mortalidade materna e infantil revelam que os cemitérios eram abarrotados por anjinhos e suas mães que precocemente haviam se transformados em molambos. Por outro lado, os homens se casavam três ou quatro vezes e se cercavam de prole numerosa, 15 a 20 filhos. O tenebroso cenário foi descrito com essas palavras:

Nossos avós e bisavós patriarcais, quase sempre grandes procriadores, às vezes terríveis sátiros de patuá de Nossa Senhora sobre o peito cabeludo, machos insaciáveis colhendo do casamento com meninas todo um estranho sabor sensual, raramente tiveram a felicidade de se fazerem acompanhar da mesma esposa até a velhice. Eram elas que, apesar de mais moças, iam morrendo; e eles casando com irmãs mais novas ou primas da primeira mulher (FREYRE, 1999; p. 360)

As historietas exploram bastante o relacionamento de uma mocinha com sua madrasta. A idade das mocinhas é incerta em muitos casos, mas indubitavelmente elas são pré-adolescentes. A presença de madrastas revela que as mães morriam precocemente, devido a doenças oportunísticas e aos elevados custos energéticos da atividade reprodutiva - as mulheres casavam muito cedo, não existia controle da natalidade e as gestações seqüenciadas tornavam as mocinhas alvos fáceis da febre puerperal. Mortes de crianças e mulheres jovens eram fenômenos triviais, de modo que os viúvos engendravam outro casamento antes que as lágrimas enxugassem de seus rostos. A orfandade e a convivência da criança com um adulto não-aparentado (madrasta) deu origem a um conceito bem conhecido dos especialistas em psicologia evolucionária: o "efeito Cinderela".

Efeito Cinderela é um conceito derivado da teoria do investimento parental. O conflito emerge quando uma mulher em plena capacidade reprodutiva (a madrasta) tem que optar em cuidar ou alocar recursos energéticos aos próprios filhos ou aos filhos de outra mulher. Uma vez que os cuidados parentais exigem dispêndio de energia e, ao mesmo tempo, diminui as chances de uma futura reprodução, as crianças órfãs são negligenciadas ou podem ser alvos de maus-tratos por parte da mulher jovem não-aparentada. A situação se agrava substancialmente quando há competição por recursos e a madrasta se encontra no ápice de sua capacidade reprodutiva ( 25 e 30 anos de idade). 
Evidências mostram que enteadas e enteados são susceptíveis a acidentes e violência doméstica, as quais podem resultar em mortes ou abusos sexuais (DALY \& WILSON, 1999; TOOLEY et al., 2006).

A orfandade geralmente tem graves conseqüências para as crianças, pois ocasiona perturbações emocionais, atraso no desenvolvimento físico e cognitivo e aumento da mortalidade infantil (CAMPBELL \& ZEE, 1996; DALY \& MARTIN, 1999). A natureza e intensidade de tais efeitos estão relacionadas à idade e sexo das crianças, tipo de orfandade (i.e., se a criança perdeu a mãe, o pai ou ambos) e composição da nova família (i.e., convivência com madrasta ou padrasto e meio-irmãos ou meia irmãs). Os meninos são alvos de espancamentos e negligência parental, os quais podem resultar em atraso no desenvolvimento físico e cognitivo (síndrome de Kaspar Hauser), mas geralmente eles têm melhor sorte que as meninas. À medida que crescem e ganham corpo, os meninos se tornam menos susceptíveis aos maus-tratos e se transformam em arrimo da família. Meninas também são susceptíveis a tais abusos, mas o crescimento físico não reduz significativamente a vulnerabilidade e acrescenta outro problema: elas se tornam susceptíveis aos abusos sexuais (efeito Lolita, alusão ao livro de Vladimir Nabokov que descreve a paixão do padrasto pela jovem enteada). Os conflitos entre madrastas e enteadas ou enteados ainda mostram um interessante aspecto da dinâmica familiar dos contos de fadas: o distanciamento dos homens em questões que envolvem a educação dos filhos.

\section{Apenas "coisas de crianças"?}

A importância das histórias infantis ultrapassa o simples entretenimento, como as fábulas que transmitem ensinamentos morais e estimulam o discernimento cognitivo. As obras mais conhecidas foram realizadas por Esopo (escravo que supostamente vivera no século 6AC) e Jean de La Fontaine (1621-95). As fábulas exploram o papel dos animais, de acordo com o imaginário popular: as raposas são astutas, as abelhas exemplos de organização e harmonia social, os eqüinos são laboriosos, mas estúpidos e os porcos são simples glutões. O uso do modelo animal é um artifício inteligente e serve para a transmissão de ensinamentos morais ou é utilizado como para exemplificar o ideal da conduta humana.

George Orwell (1903-50) é bem conhecido por Nineteen-eighty-four (1949), livro de ficção científica que despeja sérias críticas ao sistema totalitário implantado por Josef Stalin (1879-1953) na ex-URSS, mas poucos sabem que a crítica ao totalitarismo soviético já havia sido ensaiada em Animal farm (1944). O livreto pode ser lido de um só fôlego, mas causa impressões variadas nas crianças e nos adultos. A folia antropomórfica (animais falantes, idealistas e possuidores de paixões humanas) é um recurso típico das historietas infantis, 
mas ele foi utilizado para descrever os meandros da implantação da "utopia socialista" - o livreto de Orwell pode até suscitar encantamento na mente infantil, mas o leitor adulto fica assustado com o contrabando de idéias sombrias sobre a natureza humana. $\mathrm{O}$ antropomorfismo é uma característica própria das fábulas, mas o recurso também foi bastante explorada pelos cartoons de Walt Disney (1901-66).

Os avanços tecnológicos e teorias científicas são elementos inspiradores da literatura popular e um bom exemplo é a obra de Mary Shelley (Frankenstein, or the modern Prometheus, 1818). As primeiras baterias elétricas foram desenvolvidas por Alessandro Volta (1800) e mentes imaginosas punham-se a explicar a vida como um fenômeno elétrico. Essa foi a fonte de inspiração para a criatura desenvolvida pelo Dr. Victor Frankenstein - um punhado de peças anatômicas que ganhara vida a partir da eletrificação. Outra inovação tecnológica que causou forte impressão foram os espelhos. Os antigos imaginavam que a imagem refletida numa lâmina de água representava o outro lado da pessoa, mais especificamente a sua alma. Os espelhos iniciais refletiam precariamente as imagens, mas eles causavam forte impressão.

O temor em contemplar a própria imagem é antigo, como podemos ver na trágica história de Narciso. Ele era dotado de beleza esplêndida, mas os deuses o informaram ele nunca poderia contemplar a própria imagem. Após um dia repleto de correrias, Narciso busca as águas de uma fonte, ocasião em que tem oportunidade de contemplar suas belas feições refletidas na lâmina de água; apaixonado pela imagem, ele vai ao seu encontro e morre afogado. Outra versão explica que, mergulhado numa "contemplação narcisística", o seu corpo acaba se enraizando nas margens do lago e se transforma na flor que leva o seu nome. O personagem inspirou um tipo de personalidade bem conhecida dos psicólogos: o narcisista.

Outras crenças antigas informam que, após a morte de uma pessoa, os familiares cobriam os espelhos para impedir que a alma do defunto persistisse na ligação com o mundo dos viventes. O bebê era impedido de contemplar a própria imagem refletida num espelho, pois as imagens causavam perturbações e davam origem à epilepsia. Os espelhos eram itens valiosos e, de algum modo, estavam atrelados à vida de seu proprietário - caso fossem quebrados, o desastrado tinha garantido sete anos de azar. Os espelhos promoviam a "vaidade narcisística" e despertavam temores, pois eram instrumentos utilizados pelas bruxas para visualizar o futuro (as bolas de cristal).

A popularização dos espelhos promoveu mudanças nos costumes, para bem ou para o mal: a descoberta do próprio rosto estimulou a criação dos adornos faciais e permitiu melhor percepção acerca dos sinais de envelhecimento. Eles eram utilizados para identificar os vampiros, pois tais criaturas não tinham almas e, 
portanto, os espelhos não refletiam suas imagens. A inovação tecnológica inspirou a literatura popular, como pode ser visto na historieta Branca de Neve e os setes anões (a rainha malvada indaga à sua imagem refletida num espelho acerca de sua beleza) e The picture of Dorian Gray (1891), obra do irlandês Oscar Wilde que descreve a "transferência" do envelhecimento e decadência física de seu personagem homônimo para uma pintura de seu rosto.

Relatos biográficos revelam que muitos escritores apreciavam os avanços científicos. Eles liam os periódicos ou mantinham correspondência com especialistas, como Charles Dickens (ele colecionava a revista médica The Lancet) e Thomas Mann (informava-se junto ao seu médico oncologista acerca dos sintomas de tumores raros). Outro escritor que se interessava pelas teorias de sua época foi Mark Twain. A frenologia se encontrava no auge da popularidade e muitos buscavam explicar a inteligência e os traços de personalidade a partir do exame da caixa craniana e proporção das estruturas faciais, como distância entre os olhos, tamanho e formato das orelhas, cumprimento da testa e assim por diante (ver STONE, 2003; SIMPSON, 2005).

A phrenologia e a physiognomia desapareceram do cenário científico e o próprio Mark Twain percebeu a inutilidade dessas teorias. Curiosamente, quem mais demonstrou ceticismo com essas idéias foi Carlo Collodi, o autor da conhecida Le aventure di Pinnocchio (1881-83). Após uma série de percalços, o menino-boneco é transformado num burrico e é vendido para um circo, onde se torna uma das atrações. Collodi discute alguns detalhes da frenologia e chegou a mencionar o nome de seu criador, o médico alemão Franz Joseph Gall (1758-1828). Tudo isso é relatado numa inocente história infantil, conforme as descrições de Collodi:

Respeitáveis ouvintes! Não serei eu a contar mentiras sobre as grandes dificuldades por mim enfrentadas para compreender e subjugar este mamífero enquanto pastava livremente por entre as montanhas nas planícies da zona tropical. Observai, por favor, quanta selvageria transpira de seus olhos, de modo que, tendo sido vãos todos os meios de domesticá-los para uma vida de quadrúpede civilizado, tive que recorrer diversas vezes ao suave dialeto do chicote. Mas cada minha tentativa ao invés de me dar o seu bem querer me dava maiores agruras. Eu porém, seguindo o sistema de Gales, encontrei no seu crânio uma pequena cartilagem óssea que a própria Faculdade Médica de Paris reconheceu ser aquilo o bulbo restaurador dos cabelos e da dança pírrica (COLLODI, 2002; p. 138). 
O menino-boneco se envolvia em variadas estripulias e acabou se tornando atração principal nos espetáculos de aberrações. Anões e crianças com deformidade física serviam a tais propósitos, como foi descrito num dos livros de Victor Hugo (L'homme qui rit, 1869) que descreve o rapto e uma terrível mutilação facial sofrida por um menino de dois anos. Ele era filho de um dos inimigos do Rei James II e, após o assassinato do pai viúvo, este recorre aos préstimos de um cirurgião para lhe providenciar um "sorriso permanente". Em seguida, o menino é vendido a uma trupe de vagabundos, os quais se aproveitavam de sua deformidade facial para conseguir algum rendimento. Registros históricos revelam que alguns cirurgiões perambulavam pela Europa e emprestavam suas habilidades para mutilar intencionalmente crianças e adultos, os quais eram explorados nos espetáculos de aberrações.

A exploração do trabalho infantil, comércio de crianças e infanticídios despertaram as atenções de Jonathan Swift, autor de um interessante ensaio sobre o tema (A modest proposal, 1726). Na época, os católicos e protestantes (irlandeses e ingleses) viviam às turras e crianças miseráveis perambulavam pelas ruas de Dublin, mas as autoridades não tomavam nenhuma providência para minimizar o grave problema social. O gênio polêmico de Swift logo encontrou uma solução: a sua "modesta proposta" aconselhava que os bebês irlandeses fossem engordados e, posteriormente, vendidos por preços variáveis. Era uma solução interessante, pois as famílias poderiam ter algum lucro com as vendas e a nação se veria livre de um grande número de pedintes e miseráveis que infestavam as ruas de Dublin - ao invés de infanticídios e abortos voluntários de filhos bastardos, mais por falta de recursos que por vergonha, as mães deveriam amamentar o máximo possível os bebês, pois carcaças mais gordas proporcionavam lucros maiores e serviam de repasto a um número maior de pessoas.

\section{Dinâmica do relacionamento conjugal}

Os clássicos da literatura infantil contêm informações sobre os avanços científicos e tecnológicos e revelam o modo como as famílias lidavam com suas crianças, mulheres, idosos e enfermos. O relacionamento conjugal é descrito numa linguagem bastante peculiar, mas uma observação mais atenta logo detecta fenômenos inusitados, como adultérios, uxoricídios (assassinatos de esposas) e despotismo dos maridos - espancamentos das esposas eram coisas corriqueiras e eles casavam as filhas de acordo com suas conveniências. Casos de negligência parental, abandono de crianças e infanticídios são elementos onipresentes nesse gênero literário. O conto João e sua esposa Maria descreve a lascívia e o apreço de uma mulher por bebidas alcoólicas. 


\title{
HUMANAS
}

\begin{abstract}
Havia uma moça chamada Maria. Usava sapatos que tinham saltos vermelhos e, quando saía, sempre exibia os pezinhos e era bem alegre, pensando de si mesma: - Que bonita que sou! E ao voltar para casa, para animar-se um pouco, tomava um golinho ou dois de vinho; e como o vinho aumenta o apetite, experimentava um pouquinho de tudo o que cozinhava, justificando-se: - Uma boa cozinheira tem de saber se o que prepara está ficando gostoso (Contos de Grimm, 2002; p. 86).
\end{abstract}

Maria era uma esposa negligente, pois não gostava do trabalho doméstico e a casa vivia em plena desordem. Os golinhos de vinho só faziam aumentar o seu gênio indolente. Certo dia, o marido a encarrega de colher o milho, enquanto ele resolve um problema na cidade. Maria prepara uma boa refeição e se encaminha para o milharal. Chegando lá, ela come imediatamente a refeição e se entrega a um sono longo e profundo. João retorna de seu compromisso e nota a ausência da mulher, imaginando que a "dedicada" esposa estava prolongando demasiadamente a jornada de trabalho. Veio a noite e Maria não retorna. Curioso, João foi verificar o montante de milho que fora colhido, mas nota que o milharal estava intacto e a mulher dormitava a sono solto. Furioso com a mandrionice, ele amarra uma corda cheia de sininhos em torno da cintura de Maria. Ela acorda no meio da noite e fica assustada com os barulhos dos sininhos, indagando-se a si mesma se ela, Maria, era mesmo Maria ou havia sido transformada numa outra pessoa. Ela resolve buscar ajuda do marido:

Irei até em casa e perguntarei a João se sou ou não Maria. Ele saberá me dizer. Correu então até a porta da casa e, ao encontrá-la trancada, bateu na janela gritando:

- João! A Maria está aí dentro?

- Está onde deveria estar, com certeza - João respondeu.

- Minha nossa! - ela concluiu assustada.

- Esta, então, não sou eu.

Ela se foi ela e bateu nas portas dois vizinhos, mas quando eles ouviam os sininhos, não a deixavam entrar, e, assim, por fim, lá se foi ela de volta para a plantação (Contos de Grimm, 2002; p. 101).

O comportamento lascivo, o gosto por bebidas alcoólicas e a despersonalização são descritos numa linguagem bem própria das histórias infantis, mas, 
somados, eles são indícios de graves perturbações mentais. Um episódio de voyeurismo foi descrito no conto $O$ chapim do rei (CASCUDO, 1999), o qual descreve o encantamento de um rei viúvo por uma jovem casada e de rara beleza. Ele sentia falta do calor dos braços femininos e cortejava discretamente a jovem, mas ela não retribuía sequer com um olhar furtivo em sua direção. Desesperado, o rei busca ajuda de uma escrava para contemplar o corpo da jovem, enquanto esta estivesse dormindo. O marido descobre as artimanhas do voyeur e este se sai com a seguinte trova: "Linda uva eu vi! Mas juro por c'roa minha que em tal uva não buli!" O marido pede desculpas à mulher pelas suspeitas de adultério, perdoando também ao rei viúvo e à escrava pela invasão da intimidade.

Os contos populares também descrevem a dependência das mulheres em relação aos maridos e como os casamentos eram arranjados. Eles eram realizados às pressas, sempre movidos pelos interesses pecuniários dos pais - não existiam os arrulhos e os floreios do namoro, tal como ocorre nos dias de hoje. As mulheres eram espancadas pelo desmazelo, por alguma deficiência física (surdez ou cegueira, por exemplo) ou simplesmente por que não conseguiam gerar filhos. A obra de Teófilo Braga (2002) descreve o tenebroso cenário dos contos de fadas e, interessantemente, o tom jocoso acentua ainda mais os infortúnios vividos pelas mulheres. Com efeito, o conto $A$ bengala de dezasseis quintais descreve os espancamentos de uma mulher grávida e a sua expulsão de casa; ela estava prestes a dar a luz e teve que buscar refúgio numa lapa, onde teve um menino e ambos sobreviveram se alimentando de ervas. Outra historieta (Os dois compadres) descreve os conselhos que um homem dava ao seu compadre para manter a harmonia no ambiente doméstico. O mais velho sempre espancava a esposa e o outro, não. $\mathrm{O}$ diálogo entre os dois compadres:

- Tu não bates na tua? - interrogava o mais velho. - Eu não; pois ela é tão boa e tão minha amiga; heide de agora ir bater-lhe!

- Bondades de mulheres! As mulheres para serem boas e verdadeiramente amigas de um homem, precisam ser zurzidas. E tu hás-de bater na tua. Olha, eu todos os dias toco a fogo no espinhaço da minha (BRAGA, 2002; p. 288).

O compadre malvado não dava trégua, pois a desafortunada esposa era humilhada e zurzida rotineiramente. Ela recebia bordoadas nos quartos, no espinhaço e em outras partes esquisitas do corpo. A historieta se insere na mais pura tradição dos "proveitos e exemplos" de Trancoso e, portanto, tem final feliz. Preocupadas com os espancamentos, as amigas se reúnem e elaboram um plano para dar fim aos abusos perpetrados pelo marido malvado. 
A solução foi eficaz e merece ser contada em detalhes. Com efeito, elas aconselham a comadre a apelar às Onze Virgens (Santa Úrsula e as 10 virgens que acompanharam o seu martírio) nos momentos de apuro, esclarecendo que para tanto a porta de sua casa deveria ser mantida sempre aberta para permitir a entrada das santas. Enquanto isso, o malvado continuava com suas pregações junto ao pacífico compadre: "-Não zurzistes a tua mulher?! És um bajojo!" As amigas de sua esposa se vestem de branco e, munidas de cacetes, invadem a casa na primeira ocasião em que ela é espancada e roga aos céus o socorro das Onze Virgens. O marido malvado recebe bofetões e cacetadas nas ventas que nem tambor em arraial; a pancadaria quase o deixa morto. No dia seguinte, ele era outro homem. Ao se encontrar com o compadre, o malvado o aconselha de modo diferente:

\begin{abstract}
- Mandei-te chamar para te pedir que não queiras nunca mais bater na tua mulher. Crê que são santas. Eu hoje bati na minha como de costume; mas ela, porque já não podia sofrer mais, pediu às Onze Virgens que lhe valessem, e estas não se fizeram esperar. Deram-me tanta pancadaria, que me deixaram neste estado. E olha compadre - continuou o enfermo - foi uma providência a minha mulher não se lembrar de chamar os Doze Apóstolos, porque então deixavam-me morto; sempre era força de homens (BRAGA, 2002; p. 292).
\end{abstract}

\section{Extravagâncias sexuais}

Em Rolando e Passarinho-de-Maio (Contos de Grimm, 2002) nós temos uma descrição de uma sutil extravagância sexual. Certo dia, um pobre lenhador se depara com o choro de um bebê, o qual fora roubado dos braços de sua mãe por um abutre e que se encontrava pendurado nos galhos de uma árvore. Encantado com a criança, o lenhador a recolhe e lhe dá o nome de "Passarinhode-Maio", pois fora neste mês que ela fora encontrada. A menina cresce junto com Rolando, o filho legítimo do lenhador. A família era muito pobre e a esposa do lenhador o convence a abandonar as crianças na floresta, pois o estoque de pão já estava no final. Rolando ouve a conversa e, espertamente, coleta algumas pedrinhas para marcar o caminho percorrido. Elas são abandonados na floresta, mas retornam com segurança seguindo as pedrinhas que serviram para sinalizar o caminho. Frustrada, a mulher convence o lenhador a penetrar mais fundo na floresta; o menino ouve novamente a conversa, mas não tem oportunidade de estocar as pedrinhas. Ele espalha migalhas de pão pelo caminho, mas os passarinhos devoram-nas e as crianças se perdem na floresta. 
Rolando e Passarinho-de-Maio buscam alimento e acabam penetrando na casa de uma fada malévola - nem sempre elas são bondosas! Os dois são aprisionados e por pouco não são devorados pela fada; eles escapam do cativeiro e, após outros percalços, se casam e vivem felizes o restante de suas vidas.

O conto descreve o abandono de crianças, antropofagia e o relacionamento incestuoso entre irmãos (Passarinho-de-Maio fora criada desde bebê com Rolando e, na prática, são irmãos). Entretanto, uma descrição de verdadeiro caso de incesto entre pai e filha pode ser vista em Pele-de-Asno (Contos de Grimm, 2002). Com efeito, o conto descreve que uma rainha adoentada e à beira da morte impõe ao marido o cumprimento da seguinte promessa: "Jura que jamais te casarás novamente, a não ser que encontres uma esposa tão bela como eu e que tenha os cabelos dourados como os meus". Em seguida, a rainha fecha os olhos e emite os últimos suspiros. A promessa gera um enorme problema, pois o rei envia seus mensageiros a todos os cantos do reino e ninguém encontra mulher tão bela quanto a finada rainha. $\mathrm{O}$ tempo foi passando e, repentinamente, o rei nota que a mulher tão desejada estava quase que ao seu lado: era a própria filha, pois ela herdara os cabelos dourados e as lindas feições da mãe. A menina e os cortesões se assustam com os arroubos do rei, mas ele não desiste do cumprimento da promessa. Com o intuito de provocar a desistência do pai, a jovem princesa exige o cumprimento de três pedidos extravagantes: a confecção de um vestido dourado e brilhante como o Sol, outro prateado e reluzente como a Lua e o terceiro, tão ofuscante em seu esplendor quanto o brilho das estrelas. O rei mobiliza os mais hábeis artesões e cumpre as exigências. Ele exige que a princesinha assuma o papel de esposa, mas ela foge e passa a perambular pelas florestas, dormindo em ocos de árvores. O tempo passa e todos se esquecem da existência da princesinha fujona. Entretanto, certo dia os caçadores do rei localizam a menina, mas ela não é reconhecida, pois estava sujíssima e cobria o corpo com uma horrenda pele de asno. O rei fica sensibilizado com a sorte daquela menina e, sem desconfiar que fosse a sua filha, leva-a para trabalhar em seu castelo. A mocinha ganha o apelido de Pele-de-Asno e é encarregada de realizar trabalhos árduos e variados, como varrer a cozinha, depenar aves ou buscar água e lenha. Num determinado dia, o rei resolve dar um baile no castelo e Pele-de-Asno arruma um jeito de freqüentá-lo. Ela dança com o pai, mas foge antes de ter a sua identidade revelada; ela também incita a imaginação do rei, adicionando um anel ou um colar à sua sopa. $\mathrm{O}$ rei fica intrigado sobre a identidade da jovem e esta o envolve num curioso jogo de aproximação e esquiva. Movido pelo ardor da paixão, ele segue as pistas deixadas por Pele-de-Asno e finalmente descobre a sua verdadeira identidade; diante disso, a jovem remove o horrendo capote, lava a fuligem do rosto e deixa à mostra os seus cabelos dourados e sua lindas formas. 


\section{HUMANAS}

O rei proclama: "- Serás minha amada noiva, e nunca mais nos separaremos". O casamento entre pai e filha foi imediatamente realizado e o dia se tornou cheio de alegria para todos no castelo.

\section{Mais extravagâncias sexuais}

A conduta sexual dos personagens pode ser vista na história de Rapunzel (Grimm's fairy tales, 1996). Ela era uma jovem que, aos 12 anos, fora encarcerada numa torre por uma bruxa. Rapunzel era a mais bela mocinha que vivera sob o Sol e não existia nenhuma porta ou escada que permitia o acesso ao alto da torre. Somente a bruxa sabia como chegar lá e para tal usava um estratagema: ela se aproximava e dizia "Rapunzel, Rapunzel, jogue suas tranças!" A mocinha obedecia e a bruxa usava suas tranças como se fossem cordas. Rapunzel cantarolava para vencer a solidão e a sua voz doce e melodiosa despertou a atenção de um príncipe que casualmente caçava na região. Enfeitiçado pela voz, ele despende alguns dias tentando localizar a entrada da torre, mas logo percebe o estratagema utilizado pela bruxa. Ao cair da noite, ele imita as palavras da bruxa: "Rapunzel, Rapunzel, jogue suas tranças!". Ao se deparar com o príncipe, a mocinha fica inicialmente aterrorizada, mas logo a troca de olhares e a fala gentil do rapaz removem o seu medo. Eles combinam o casamento e a mocinha propõe uma solução para ambos escaparem da torre: a cada visita noturna, o príncipe deveria trazer uma fita de seda, de forma a permitir a confecção de uma corda para a fuga de Rapunzel - a torre era alta e o leitor atento logo deduz que muitas fitas (ou visitas) foram necessárias para a confecção da corda. As visitas noturnas transcorrem normalmente, até o momento em que a jovem deixa escapar o segredo para a bruxa. Movida por uma fúria que só as bruxas exibem, ela corta as tranças de Rapunzel, joga-a do alto e ocupa o seu lugar na torre. Rapunzel passa a viver na floresta, em extrema pobreza e vivendo como se fosse um bicho. Ao se aproximar para mais uma visita noturna, o príncipe profere as palavras adequadas e a bruxa lança para baixo as tranças de Rapunzel. O rapaz fica espantando com a horrenda mulher que se encontrava diante de seus olhos, ocasião em que a bruxa proclama: "a avezinha não se encontra mais no ninho e seu canto não mais será ouvido, pois ela foi devorada por um gato". Desesperado, o príncipe busca a morte se atirando do alto da torre; ele sobrevive, mas os olhos são vazados pelos galhos de uma árvore. Cego e debilitado, ele perambula pela floresta $\mathrm{e}$ sobrevive consumindo raízes e frutos silvestres - a dor maior decorria da perda de sua amada. Após alguns anos nessa vida, certo dia ele ouve uma voz que the era muito familiar. Era Rapunzel. Ela vivia em extrema pobreza com os filhos gêmeos, frutos das inúmeras fitas que o príncipe trazia para confecção da corda. 
Os dois se abraçam longamente e a jovem acomoda maternalmente a cabeça do rapaz junto ao seu peito. Duas gotinhas de lágrimas caem e umedecem os olhos do príncipe, curando-o da cegueira. É claro que ambos viveram felizes a partir desse momento.

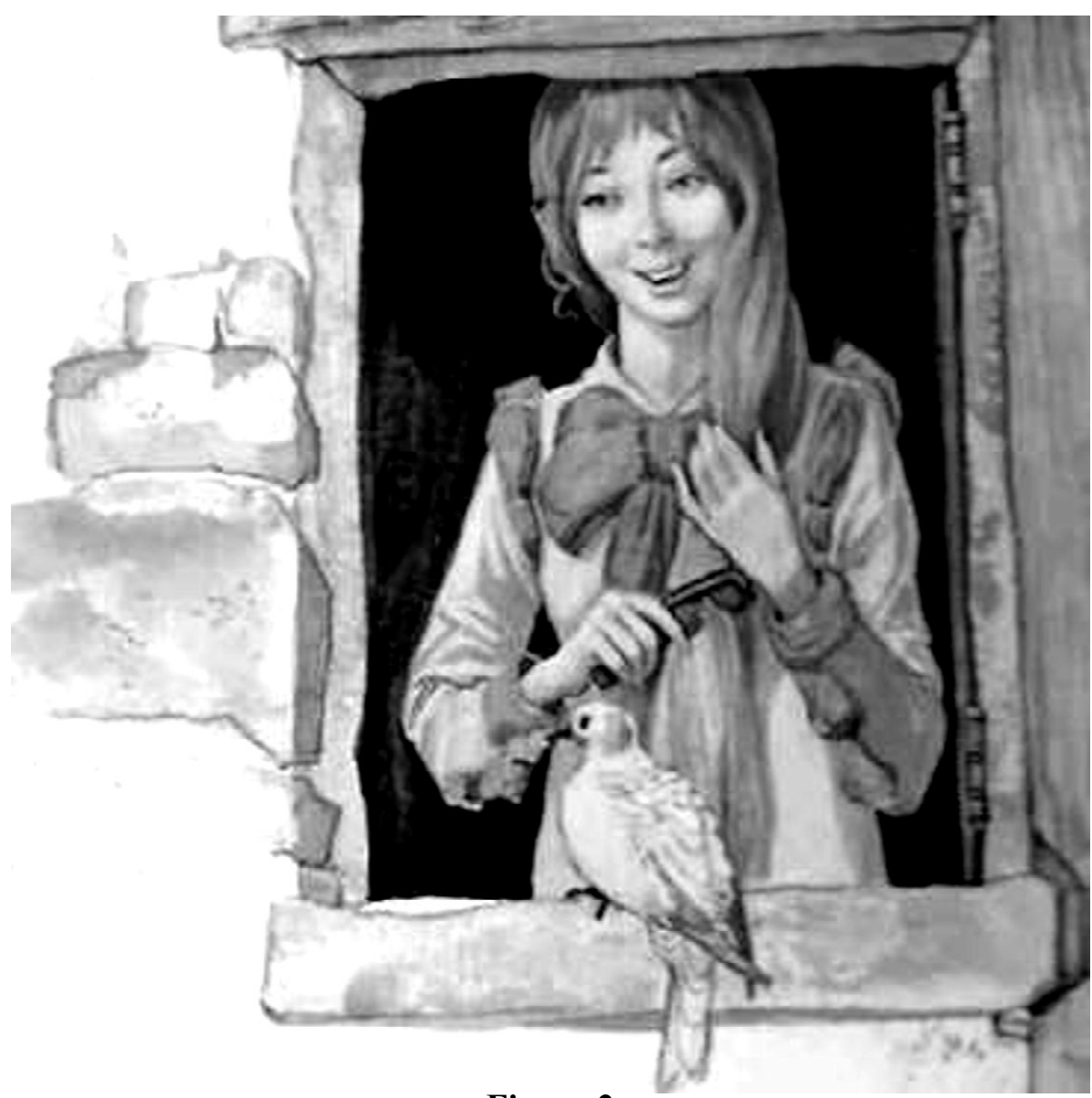

Figura 2

Rapunzel e a sua preocupação excessiva com os cabelos.

Algo ainda mais complexo pode ser visto em A afilhada de S. Pedro (COELHO, 1999), pois a temática central é o lesbianismo e adultério feminino. Um casal tinha tantos filhos, de modo que não havia mais ninguém que pudesse servir de padrinho para uma filha recém-nascida. Ao se deparar com um velhinho pelo caminho (S. Pedro escondido em andrajos), o pai da criança relata suas dificuldades. O estranho velhinho o tranqüiliza, mas impõe duas condições: "põe-lhe o nome de Pedro e, quando ela tiver sete anos, 
hás-de ma trazer aqui a este sítio". De acordo com o combinado, o pai entrega a filha aos cuidados de S. Pedro; ela é bem tratada e recebe o conselho para nunca se vestir de mulher. A mulher-homem encontra emprego num palácio e informa que seu nome era Pedro; a sua função era guardar os patos. Encantada com a beleza do "rapaz", a rainha faz uma visita noturna aos seus aposentos, mas Pedro foge de seus braços. Aborrecida com a recusa, a rainha o intriga junto ao rei, dizendo que Pedro lhe dissera ser capaz de localizar um anel que ela havia perdido no fundo do mar. Diante do inusitado desafio, Pedro recorre ao santo padrinho, o qual the aconselha a comprar um peixe, pois dentro de seu bucho estaria o anel da rainha; foi o que de fato aconteceu. No dia seguinte, a rainha invade novamente os aposentos do rapaz-mulher, mas novamente Pedro escapa do consórcio carnal. Como vingança, a rainha informa ao rei que Pedro havia the dito ser capaz de "moer um moio" de trigo em apenas uma noite; novamente S. Pedro vêm em socorro do "afilhado" e providencia a execução da tarefa. A insaciável rainha novamente bate às portas do quarto de Pedro, mas novamente ele escapa de seus braços; ela o intriga junto ao rei, dizendo que este dissera ser capaz de resgatar a filha muda que se encontrava encantada entre os "moiros". O afilhado de S. Pedro cumpre a missão, mas a rainha não se dá por vencida e exige que ele devolva a voz à filha muda. Isto não era possível e, assim sendo, Pedro já se preparava para morrer enforcado. $\mathrm{O}$ padrinho vem em seu socorro e o instrui a formular três perguntas à muda. Isso é feito e imediatamente a princesa recupera a fala e aproveita a ocasião para denunciar Pedro, dizendo que ele "é fêmea, apesar de todos julgarem ser ele macho". Diante disso, o rei manda descê-lo da forca, ordena a morte da rainha intrigante e passa a viver com a nova esposa, o rapaz-moça.

Muitas vezes a sensualidade nos enredos só é detectável com uma boa lupa, mas em certas ocasiões as extravagâncias são bem evidentes. Com efeito, $O$ sarjatário (ROMERO, 2000) descreve a paixão de um rei solteiro por Maria Gomes, moça que se vestia de homem. Ela era filha de um pescador e fora prometida a uma entidade (uma voz misteriosa vinda não se sabe de onde), em troca de fartura de peixes. A moça recebe os conselhos de um cavalo encantado (São Pedro, no conto anterior) e passa a se vestir como se fosse um rapaz. Ao chegar a uma cidade, o "mancebo" desperta as atenções de um rei solteiro, mas o seu comportamento e as vestimentas não convencem a sua mãe. Os dois logo se tornam amigos, mas a mãe do rei o aconselha: "aquele teu amigo não é homem, é mulher". Os conselhos não são levados a sério, de modo que a mãe propõe um modo inteligente de testar a masculinidade do estranho jovem. Ela pede que o filho leve o amigo para um passeio pela cidade, para ver o que mais lhe agrada aos olhos - se dos objetos dos homens ou se dos objetos das senhoras e damas. 
$\mathrm{O}$ cavalo falante denuncia ao jovem que ele estava sendo posto à prova e o instrui a pousar os olhos somente em objetos masculinos. Outro teste é realizado e, novamente, o cavalo falante ajuda Maria Gomes a se passar por homem. Nada disso convence a sagacidade materna, pois a mãe induz o filho a convidar o "amigo" a pernoitar no castelo. O objetivo era explorar a anatomia de seu corpo para verificar o verdadeiro sexo. Maria Gomes tenta manter-se acordada, mas sucumbe ao sono. Por volta das quatro horas da madrugada, o rei adentra os aposentos do "amigo" e realiza o teste final. Ele tem uma surpresa:

\begin{abstract}
Aí o rei veio devagarinho e desabotoou-lhe a camisa e pegou nos seios, que ali estavam durinhos e guardadinhos... O rei, quando lhes botou a mão em cima, foi dizendo: "Oh! Senhora dona!" Aí apareceu logo a mãe do rei e deu à moça roupas de mulher, e ela muito envergonhada, pediu desculpas ao rei, que logo a pediu em casamento (ROMERO, 2000; p. 193).
\end{abstract}

Um conhecido conto popular ( $A$ filha que amamenta o pai) informa o leitor sobre o modo como os prisioneiros eram tratados durante o período medieval (i.e., submetidos aos ferros e privados de alimento), ao mesmo tempo em que descreve os estranhos procedimentos adotados por uma filha para salvar o pai da fome. Todos os anos o rei perdoava um prisioneiro condenado à morte, desde que fosse proposto um enigma que lhe fosse impossível de ser elucidado. Uma jovem apresentou-se a ele e lançou o desafio: “- Já fui niña, aora soy madre. Alimento mi padre, marido de mi madre, avó de mi hijos". $\mathrm{O}$ rei pensou e pensou, mas não conseguiu chegar à resposta certa. A jovem explicou: o seu pai estava preso e o amamentou às escondidas para livrá-lo da fome. Espantado, o rei teve que soltar o pobre homem (BRAGA, 2002).

Outra peculiaridade desse tipo de literatura é o comércio de mulheres. Os pais casavam as filhas aos doze ou treze anos de idade, sempre de acordo com suas conveniências e pensando em benefícios futuros. A virgindade era um bem precioso e os enredos anacrônicos manifestam claramente as preocupações dos pais acerca da "pureza" das filhas. A linguagem é cheia de rodeios e o conto Dona Pinta revela o modo como tal preocupação se manifestava. Ele descreve que um velhote tinha três filhas bonitas e virgens. Ao ser forçado a empreender uma longa viagem, para combater nas guerras de seu reino, ele presenteia as filhas com três rosas e as instrui: "Quando voltar, cada uma há de me apresentar a sua rosa aberta e fresca, que é sinal de sua virgindade; aquela cuja rosa estiver murcha, terá meu castigo" (ROMERO, 2000; p. 87). 
O que são essas rosas abertas e frescas? Não é preciso muito o exercício da imaginação para deduzir que são os órgãos sexuais femininos.

As virgens eram sacrificadas aos deuses e a pureza virginal era até capaz de amansar os terríveis unicórnios - a criatura imaginária descansava a cabeça no colo de uma virgem, ocasião em que se entregava ao sono enquanto o seu chifre era docemente acariciado. $O$ sangue das virgens curava a lepra e suas secreções (saliva, suor e os mênstruos) tinham poderes terapêuticos extraordinários ou eram itens essenciais nos rituais de feitiçaria. Como os anjinhos que morriam antes da primeira amamentação, as virgens não tinham vínculo terreno, pois não foram maculadas pelo sexo, e tinham acesso privilegiado no reino dos céus. Elas nunca recebiam pena capital, mas, em casos extremos, os próprios carrascos se encarregavam de desvirginá-las para o cumprimento da sentença. $\mathrm{O}$ culto à virgindade é facilmente detectável na mitologia Greco-romana e na tradição judaico-cristã. $\mathrm{O}$ fenômeno não tem uma única explicação, mas está essencialmente relacionado aos elevados custos da atividade reprodutiva e possibilidade de transferência de agentes patogênicos (doenças sexualmente transmissíveis, DST). O recato feminino é uma estratégia evolucionária estável e a valorização da virgindade é um traço marcante das histórias infantis.

\section{Como morriam nossas criancinhas?}

Autores de obras densas e mais direcionadas ao leitor adulto também enveredaram pela literatura infantil. Com efeito, Fiodor Dostoyevsky (182181) é bem conhecido por suas discussões sobre injustiças sociais, miséria e dilemas existenciais, mas poucos sabem que ele é autor de $A$ árvore de Natal na casa de Cristo" (1848). Trata-se de uma pungente historieta infantil que descreve a morte trágica de uma criança, tema difícil de ser abordado até pelos mestres das letras. Tudo tem início quando um garotinho de seis anos, ou menos, desperta na noite de Natal num porão frio e úmido. Faminto e vestindo molambos, ele percebe que a mãe não mais se mexia e o seu corpo estava tão frio quando as paredes escuras do porão. A mulher que alugara o porão fora presa na antevéspera e os moradores haviam saído para aproveitar o clima festivo do Natal. Só restavam uma velha octogenária que morria lentamente, misturando muxoxos e imprecações, e um tapeceiro que ruminava uma bebedeira de dois dias. O menino abandona o porão em busca de alimento ou algo para se esquentar, sem sucesso. Os sinais da hipotermia logo começam a se manifestar, pois seus pés doem e as extremidades de seus dedinhos endurecem e se tornam arroxeadas. Ele sopra as mãos, mas os efeitos do bafo são tênues e passageiros. Ao contemplar uma vitrine cheia de enfeites de Natal, um garoto malvado se aproxima e dá-lhe um tapa; ele sai em disparada e encontra abrigo numa cocheira. 
Os efeitos do frio intenso e do estômago vazio se somam ao fôlego exaurido na correria, de modo que o garotinho se acomoda num monte de lenha e logo começa a ter uma estranha sensação de bem-estar. As dores nos dedinhos desaparecem e o seu corpo é envolto por um calor reconfortante, como se ele estivesse próximo a um fogão à lenha. As alucinações ganham mais intensidade e novas matizes: o garotinho começa a pensar em brinquedos e ouve a voz de sua falecida mãe; ela surge diante de seus olhos e estende os braços como se estivesse o convidando para junto de si. O garotinho percebe um grupo de crianças alegres e barulhentas que brincavam em torno de uma árvore de Natal. Ele é envolvido numa doce algaravia e os amiguinhos lhe reconfortam dizendo que eram anjinhos, os quais foram abençoados por Cristo e ali estavam para recepcionar as crianças que pereciam congeladas, abandonadas pelas mães em cestos nas escadarias dos palácios de Petersburgo. O pobre garotinho ficou feliz, mas tudo aquilo foi fruto de uma imaginação delirante: no dia seguinte os trabalhadores encontraram o cadaverzinho gelado e, mais adiante, estava o corpo de sua mãe. Ambos se reencontraram no céu, abençoados por Deus (ver DOSTOYEVSKY, 2007).

Outro conto infantil descreve mais detalhadamente as alucinações decorrentes da prolongada exposição ao frio. Com efeito, o conto A pequena vendedora de fósforos (ANDERSEN, 1974) descreve a morte de uma garotinha no anoitecer da última noite do ano (pleno Inverno no hemisfério norte). $O$ frio era intenso, caia muita neve e a menininha se encontrava completamente desprotegida; nada cobria a sua cabeça e ela perdera os chinelos (um deles quando tentava se esquivar de duas carruagens que vinham desgovernadas, o outro fora roubado por um garoto). Seus pezinhos estavam arroxeados, ela tremia de frio e estava faminta. A situação era de extrema miséria. Ela trazia alguns fósforos no avental, mas não conseguia vender nenhum - esse detalhe esclarece que os fósforos eram itens valiosos em outros tempos. Os flocos de neve caiam sobre seus cabelos, formando lindos cachos em torno de seu pescoço. Dentro das casas, as pessoas comemoraram a véspera do Ano Novo, regalando-se com deliciosos guisados. Ela não podia voltar para casa por dois motivos: seu pai lhe espancaria pelo insucesso nas vendas e porque a casa, cheia de furos e frestas, era tão fria quanto as ruas. Suas mãozinhas já estavam enrijecidas pelo frio e ela teve a idéia de acender um fósforo para aquecê-las. Feito isso, a luz e o calor proporcionaram uma fugaz sensação de bem-estar; ela faz uma concha com as mãos e começa a imaginar que se encontrava diante de um grande fogão à lenha. A sensação foi maravilhosa, mas durou pouco. Ela acende um novo fósforo e se depara com uma esplêndida visão: uma enorme mesa de jantar, coberta com uma toalha alvíssima; um ganso assado exalava um odor delicioso, misturado com o recheio de maçãs e ameixas. 
A criança já exibia as alucinações típicas da hipotermia e, com efeito, ela nota que repentinamente o "ganso assado" escapa da travessa e, espetado com garfos e facas, desajeitadamente se aproxima em sua direção. A chama do fósforo se apaga e a noite volta a se tornar tão fria e úmida quanto antes. Outro fósforo é aceso e a garotinha tem uma visão diferente: ela se vê debaixo de uma linda árvore de Natal; ela fica encantada com as velas e os cartões que adornavam a árvore, mas o fósforo se apaga e as luzes sobem para o céu, como se fossem estrelas. Uma das "estrelas" cai e forma uma trilha luminosa no céu escuro. A garotinha logo deduz: "Alguém está morrendo". Ela acende outro fósforo e a sua vovozinha surge diante dela, com feições ternas e bondosas. "Vovó, leve-me com você", pede a garotinha. "Eu sei que o apagar das chamas fará você desaparecer, tal como ocorreu com o calor do fogão, o ganso assado e a linda árvore de Natal", acrescenta a menina. Ato contínuo, ela acende todos os fósforos restantes, é acolhida pelos braços da vovozinha e juntas voam para o mais alto possível, onde não havia frio, fome e outras atribulações trata-se de uma alegoria, pois o frio se torna mais intenso nas alturas. Como no conto de Dostoyevsky, no dia seguinte os transeuntes se deparam com o corpinho sem vida da menina; ela estava sentada e exibia faces rosadas e um sorriso nos lábios. Ela fora ao encontro de Deus.

As duas historietas descrevem os efeitos fisiológicos e as perturbações mentais decorrentes da exposição prolongada ao frio. Os detalhes são precisos e realistas. Em condições normais, a temperatura do corpo oscila entre $36,2^{\circ} \mathrm{e}$ $37,5^{\circ} \mathrm{C}$ e a hipotermia ocorre quando ela decai para abaixo de $35^{\circ} \mathrm{C}$. O quadro clínico se agrava em razão do tempo de exposição ao frio e dão surgimento aos seguintes sintomas: redução no tempo de reação, confusão mental, alucinações e perda da consciência. A falta de alimento agrava os sintomas da hipotermia, pois a digestão libera calor nas células e, portanto, minimiza os efeitos da queda da temperatura do ambiente. A pessoa tende a se aconchegar num canto, mas logo perde a consciência e morre em seguida. O conto de Andersen é mais elucidativo sobre a natureza da perturbação mental da garotinha: ela sonha com alimento e o calor dos braços ternos da avó.

\section{A morte de Partlet e a tristeza de Chantecler}

As histórias infantis ajudam as crianças a lidarem com temas complexos, como amizade, o sentido da vida e as paixões que movem o ser humano. No que diz respeito à morte, as crianças não entendem o significado do fenômeno, em razão da imaturidade cognitiva e porque dificilmente elas vivenciaram o falecimento de uma pessoa da família. Embora muitas histórias contenham uma mensagem final positiva, algumas são trágicas do começo ao fim e cumprem a função de preparar a criança para as adversidades da vida. 
O conto "A bela adormecida" lida com a morte, mas o clima sombrio e triste é atenuado pelo estranho ressuscitamento da jovem. Não obstante o irrealismo, os pais e os psicoterapeutas podem utilizar esse tipo de narrativa para preparar ou ensinar as crianças a lidarem com os problemas da vida (ver BOKEY \& WALTER, 2002; SEDNEY, 2002). Os cartoons, encenações de peças teatrais e, é claro, os relatos orais também contribuem para o discernimento cognitivo ou prepararam as crianças para os enfrentamentos da vida real.

O enfoque é muito diferente de uma obra devotada ao leitor adulto, como ocorre no conto A morte de Ivan Illich (1886), de Leon Tolstoy. O personagem é acometido por uma misteriosa doença e as dores intensas e o progressivo debilitamento físico ocasionam profundas alterações no estado emocional. Tolstoy não oferece detalhes sobre a enfermidade, mas certamente se tratava de um câncer no aparelho digestivo. Os especialistas que lidam com pacientes em estágio terminal formularam um conceito que descreve as flutuações seqüenciadas no estado emocional que emergem a partir do momento em que o indivíduo se depara com a aproximação da "verdade fundamental", a morte. Trata-se da síndrome do FAGS, acrônimo que junta as letras iniciais de Fear/ medo, Anger/raiva, Guilt/culpa e Sadness/tristeza (ROTHENBERG, 1979).

Os personagens das histórias infantis morrem de modo trágico, mas muitas dessas mortes se inserem num esquema catártico. Por exemplo, o conto $O s$ três coroados (ROMERO, 2000) descreve a inveja de duas jovens pela irmã caçula que conseguira se casar com um rei. A mocinha deu à luz a três príncipes, mas as irmãs invejosas substituíram os bebês por um sapo, uma cobra e um gato. Frustrado, o rei resolve castigar a esposa de um modo estranho: ele ordenou que ela fosse enterrada até o pescoço para que todos cuspissem em seu rosto. As irmãs invejosas lançaram ao mar os filhos da rainha, mas foram resgatados por um pescador. Eles crescem e retornam ao castelo, ocasião em que o rei percebe que se trata de seus filhos e que agira de modo injusto em relação à esposa. Ela é desenterrada e recupera a beleza original. O que fazer em relação às duas irmãs invejosas? Os próprios sobrinhos apontam a solução: elas são amarradas a dois burros e morrem lascadas ao meio. Apedrejamentos, decapitações ou afogamentos são os espetáculos catárticos mais comuns nas inocentes histórias infantis.

É verdade que nem sempre a morte é tratada de modo violento, como ocorre na interessante historieta As aventuras do galo Chantecler e da galinha Partlet (Contos de Grimm, 2002). Ele descreve os efeitos do luto e a perda do significado da vida, temas complexos que foram abordados com o recurso do antropomorfismo. Diferentes animais viviam num clima alegre e inocente, sem rivalidades ou antagonismos, mas a morte da dama Partlet, companheira de Chantecler, interfere negativamente na doce harmonia da comunidade. 
A tragédia ocorre quando eles resolvem sair para coletar nozes, assumindo o compromisso de dividir o alimento entre os dois. A gulosa Partlet encontra uma enorme noz e a devora às escondidas, resultando num terrível engasgo. Ela implora por um gole d'água e Chantecler corre em direção à fonte para atender aos apelos da galinha, mas a fonte lhe diz: "- corre primeiro até à minha noiva e peça-lhe uma fita de seda para puxar a água". O galo sai em disparada em direção à noiva, mas esta exige: "- vá primeiro ao jardim e pegue a minha grinalda que eu deixei pendurado no salgueiro". Chantecler foi correndo ao jardim, pega a grinalda pendurada no galho do salgueiro e a entrega à noiva, que lhe deu a fita de seda vermelha. Ele entrega a fita de seda à fonte, que lhe entrega um bocado de água. Ele corre com o bocado de água, mas toda a correria foi inútil: Partlet havia morrido engasgada com a noz.

O simpático casal era estimado pelos animais da floresta e todos resolvem acompanhar o enterro de Partlet. Seis camundongos constroem e se encarregam de puxar uma pequena carruagem fúnebre; os amigos do casal (raposa, lobo, urso, cervo e o leão) se juntam ao cortejo, mas todos morrem afogados ao tentarem atravessar um riacho. Sensibilizada pelo infortúnio dos animais, uma pedra se ergue do fundo das águas e, dessa forma, permite a travessia segura de Chantecler com o corpo sem vida de Partlet. Ao final, o galo cava um buraco, deita o corpo da amiga no fundo e sinaliza o local com um montículo de terra. Chantecler se senta sobre a sepultura da amada e chora copiosamente, até que a morte sobrevém e "assim todos estavam mortos".

A primeira parte do consórcio amoroso é bastante alegre, mas o final mostra os efeitos do luto e a perda do significado da vida. A traição de Partlet foi decorrente de sua gulodice e a pobre galinha recebeu um castigo desproporcional e definitivo. Todos os amigos também são castigados, mas a tristeza de Chantecler é comovente - o fiel companheiro perde a vontade de viver, não abandona a sepultura de Partlet e a perturbação emocional logo o conduz à morte. As descrições da tristeza do galo Chantecler são realistas e se assemelham à depressão que se instala numa pessoa, resultante da morte de um cônjuge ou parente mais próximo. Os familiares e os próprios especialistas às vezes se surpreendem com o rápido debilitamento físico e emocional do homem ou da mulher que se seguem à viuvez, principalmente em casos de convivência longa e harmônica. $\mathrm{O}$ estresse da viuvez interfere no sistema imunológico, ocorre perda do apetite e negligência ao uso de medicamentos. Como ocorreu na simpática historieta dos irmãos Grimm, o "galo Chantecler" mergulha num profundo vazio existencial (helplessness) e rapidamente vai ao encontro de sua "amiga Partlet". 


\section{Doença neurodegenerativa e horror à velhice}

$\mathrm{O}$ ambiente dos contos de fadas era hostil aos idosos, deficientes físicos e mulheres jovens. Os indivíduos das duas categorias iniciais eram abandonados à própria sorte e sequer recebiam a cota de ração necessária à sobrevivência. Alguns contos descrevem o abandono de crianças nas florestas, como o clássico Joãozinho e Maria. Por seu turno, os idosos são personagens quase inexistentes ou vivem segregados do convívio social.

Como foi discutido anteriormente, o tratamento dispensado aos semoventes era movido por critérios utilitários, mas algo parecido também ocorria em relação aos idosos e crianças portadoras de necessidades especiais. O abandono de crianças foi uma prática institucionalizada durante o período da colonização do Brasil, como atestam as casas-da-roda e o asilo dos expostos. As famílias não despendiam muito tempo e energia com os idosos adoentados e chegavam a adotar procedimentos curiosos para abreviar seus infortúnios. Com efeito, os antigos portugueses recorriam às habilidades das despenadeiras, mulheres resolutas e despachadas que cravavam vigorosamente os cotovelos no peito do enfermo para abreviar o seu sofrimento (BRAGA, 1995). Os idosos imploravam para não serem despenados ou escondiam os sinais de uma enfermidade, mas eles estorvavam a rotina doméstica e os familiares agradeciam os préstimos das despenadeiras.

A historieta $O$ velho e o seu neto (Grimm's fairy tales, 1996) mostra a evolução de uma doença neurodegenerativa (mal de Parkinson) e o modo como os familiares lidavam com os transtornos causados pelos idosos. O velhote levava uma vida infeliz e seus achaques eram agravados pela escassez de alimento e rejeição dos familiares - somente o neto lhe dispensava alguma afeição. Seus olhos haviam perdido o brilho e ele tinha sérias dificuldades visuais (provavelmente devido à catarata). $\mathrm{O}$ velhote caminhava com dificuldade, pois as pernas não mais sustentavam o corpo e as mãos tremulavam continuamente. $O$ filho e a nora proibiram-no de se sentar à mesa para realizar as refeições, pois suas mãos tremiam tanto que a sopa acabava sendo derramada sobre a toalha da mesa. Para evitar este aborrecimento, ele fora obrigado a permanecer sentado num canto, próximo ao borralho do fogão à lenha. $\mathrm{O}$ alimento lhe era oferecido numa tigela de barro e em pequena quantidade, para evitar o desperdício. Certo dia, seus tremores eram tanto que a tigela escapou de suas mãos, quebrando-se em vários pedaços. Diante dos vitupérios da nora, o pobre homem abaixa a cabeça resignadamente e cai num completo mutismo. Com o intuito de evitar novo prejuízo, a mulher compra uma tigela de madeira, mas não fornece nenhum alimento ao velhote, talvez como punição ao seu comportamento desajeitado ou porque não sobrara dinheiro para o rancho. No dia seguinte, todos se encontravam sentados à mesa e surge o neto trazendo alguns pedaços de madeira. 
"O que você está fazendo", pergunta o pai. "Eu estou colhendo madeira para fazer um cocho", respondeu o menino. "Ele servirá de prato para você e mamãe, quando eu for grande". Marido e mulher se entreolharam e as lágrimas inundaram seus olhos, pois vislumbraram o mundo triste e cinzento que os aguardava na velhice. Eles se aproximam e puxam o velhote pelas mãos, conduzindo-o à mesa. Desde então ninguém mais ralhou com ele, mesmo quando seus tremores causavam derramamento do precioso alimento na mesa.

O conto Pedro, o guardador de cabras (Contos de Grimm, 2002) descreve a vida de um personagem que exibia alguns sintomas da esquizofrenia (e.g., alucinações auditivas e visuais, dificuldades mnemônicas e despersonalização). A história tem como cenário a Floresta Hartz, local habitado por fadas e duendes malvados que dançavam à noite e onde, de tempos em tempos, o imperador Frederico Barba Vermelha se reunia com membros de sua corte. Pedro conduzia as cabras dentro da floresta e, ao anoitecer, achava mais conveniente dormir junto com a alimária no sopé da montanha. Por mais cuidadoso que fosse, ele notava que a cabra mais valiosa escapulia, mas retornava de manhã como se nada tivesse acontecido. Pedro montou guarda para acompanhar a fuga de sua cabra favorita e acaba descobrindo que ela escapulia através de uma fenda, vindo a se refugiar numa caverna. Chegando lá, Pedro apurou os sentidos e ouviu alguns cavalos relinchando e pisoteando o chão, mas, espantosamente, o som vinha do teto da caverna. Surge um jovem pajem que o conduz à presença de 12 cavaleiros de postura solene e trajando roupas antiquadas (alusão aos apóstolos da cristandade). Sentindo-se à vontade, ele acaba provando a bebida de um barril, o qual exalava um inebriante odor de vinho antigo. $\mathrm{O}$ guardador de cabras adormece, recupera suas forças e acorda num local que lhe era familiar, exceto que não havia cabras ao seu redor, seu cão desaparecera e a vegetação havia crescido bastante. Ele retorna para sua vila, mas nota que ninguém lhe era familiar, todos vestiam roupas esquisitas e pareciam falar um idioma diferente. Quando ele pergunta sobre o seu rebanho, as pessoas punham a mão no queixo e ele, sem se dar conta, imita o gesto e fica espantado ao constatar que a sua barba crescera uns cinqüenta centímetros! Ninguém o reconhece, mas repentinamente surge uma moça com uma criança no colo e outra sendo puxada por uma das mãos. Pedro notara que as três tinham rostos semelhantes ao de sua esposa. Ele pergunta à moça o nome de seu pai e ela diz: "-Que os céus o tenham! Era Pedro! Já se fazem vinte anos que o procuramos dia e noite pelas montanhas. Seu rebanho voltou, mas dele ninguém mais soube. Eu tinha então sete anos". As idéias ganham novo ordenamento na cabeça do guardador de cabras, pois ele prontamente percebe que estava diante da própria filha. Abraça-a efusivamente e diz ser seu pai. Todos ficam admirados com o retorno de Pedro: "-Sim, é o Pedro! Bem-vindo, vizinho, bem-vindo à casa, depois de vinte longos anos!" 
Alucinações auditivas e visuais, perturbações mnemônicas e despersonalização são sintomas típicos da esquizofrenia. A curiosa historieta também revela que Pedro padeceu por muitos anos da enfermidade e que os sintomas foram atenuados quando ele é acolhido pela família. A mensagem final é plenamente condizente com os modernos procedimentos psicoterapêuticos, os quais recomendam maior participação dos familiares no tratamento.

\section{Nanismo e deficiência mental}

Sacis, duendes e gnomos são personagens do imaginário popular. Eles representam a sagacidade e o lado pândego do gênero humano. Por seu turno, desde o final do século 17 que os anões (gente de placer) eram utilizados para o entretenimento nas cortes européias. Os pais vendiam ou ofereciam como presente os filhos anões aos reis e rainhas; muitos exibiam deficiência mental, mas isso os tornava ainda mais valorizados (HAWORTH \& CHUDLEY, 2001). Os anões são personagens comuns nas histórias infantis e, mais tarde, emprestaram a suposta "naturalidade cômica" aos espetáculos circenses, cartoons e programas infantis veiculados na TV.

Os anões eram personagens secundários na história original de Branca de Neve, pois nenhum deles tinha nome e tampouco dispomos de informações sobre suas personalidades. De acordo com a versão dos irmãos Grimm (Contos de Grimm, 2002), sabemos apenas que eles eram mineradores, trabalhavam durante todo o dia e só retornavam ao lar à noite. Nada sabemos sobre seus hábitos, mas o cartoon de Walt Disney (Snow White and the seven dwarfs, 1937) tornou-os excessivamente infantilizados, em termos morfológicos e comportamentais, e pespegou-lhes distúrbios neurológicos ou de personalidade. Eles foram apelidados de acordo com tais anomalias comportamentais: Grumpy, Sneezy e Sleepy (Zangado, Atchim e Soneca, respectivamente).

O líder dos anões (Mestre, ou Doc) sofria de um tipo especial de parafasia, pois ele repetia ou trocava as palavras e o circunlóquio indicava uma dificuldade na expressão do pensamento (BIRAN \& STEINER, 2001; ROSENFIELD, 2001). Apesar de tudo isso, ele era o mais inteligente e o nome que Disney lhe dera confirma isto - doc é o modo informal como as pessoas designam os doctors/médicos. Os anões ainda sofriam de flutuações de humor, narcolepsia, problemas respiratórios, mas Dunga (ou Dopey) era quem exibia as perturbações mais graves. Com efeito, o cartoon mostra que ele tinha dificuldades motoras e de expressão verbal (sem interferência na compreensão), sua face ostentava um sorriso constante, com marcada tendência a protrusão de língua. $\mathrm{O}$ estrabismo era ocasional e Dunga demonstrava contentamento exagerado diante de eventos triviais (batia palmas compulsivamente e movimentava as orelhas). 
UMANAS

Ele era o único que tinha olhos azuis, característica que ressaltava a sua ingenuidade - dopey é uma gíria que significa tonto ou apalermado, no idioma de Disney.

Dunga e Mestre são personagens antagônicos, pois um é apalermado e o outro, o mais esperto do grupo. Parece que Dunga sofria de uma rara anomalia neurológica que afeta $1 / 12.000$ crianças. O distúrbio foi designado síndrome da criança fantoche (Happy puppet syndrome), mas logo os especialistas passaram a chamá-lo síndrome de Angelman, homenagem à Harry Angelman (191596), médico inglês que descrevera o distúrbio. Os sinais e sintomas da doença emergem no final da infância ou início da meninice e são de vários tipos, como microcefalia, cabelos claros e olhos azuis, lábio superior acentuadamente fino e queixo pouco desenvolvido. A epilepsia ocorre em cerca de $90 \%$ dos casos e as crianças exibem dificuldades motoras (ataxias) e profundo retardo mental. Elas choram pouco, são menos irritadiças e sorriem ou dão largas risadas facilmente, embora em contextos inapropriados (HORSLER \& OLIVER, 2006). Parece que os displays comportamentais não refletem o verdadeiro estado emocional, pois a criança responde a pequenos estímulos de modo exagerado, fora de contexto ou as respostas surgem espontaneamente.

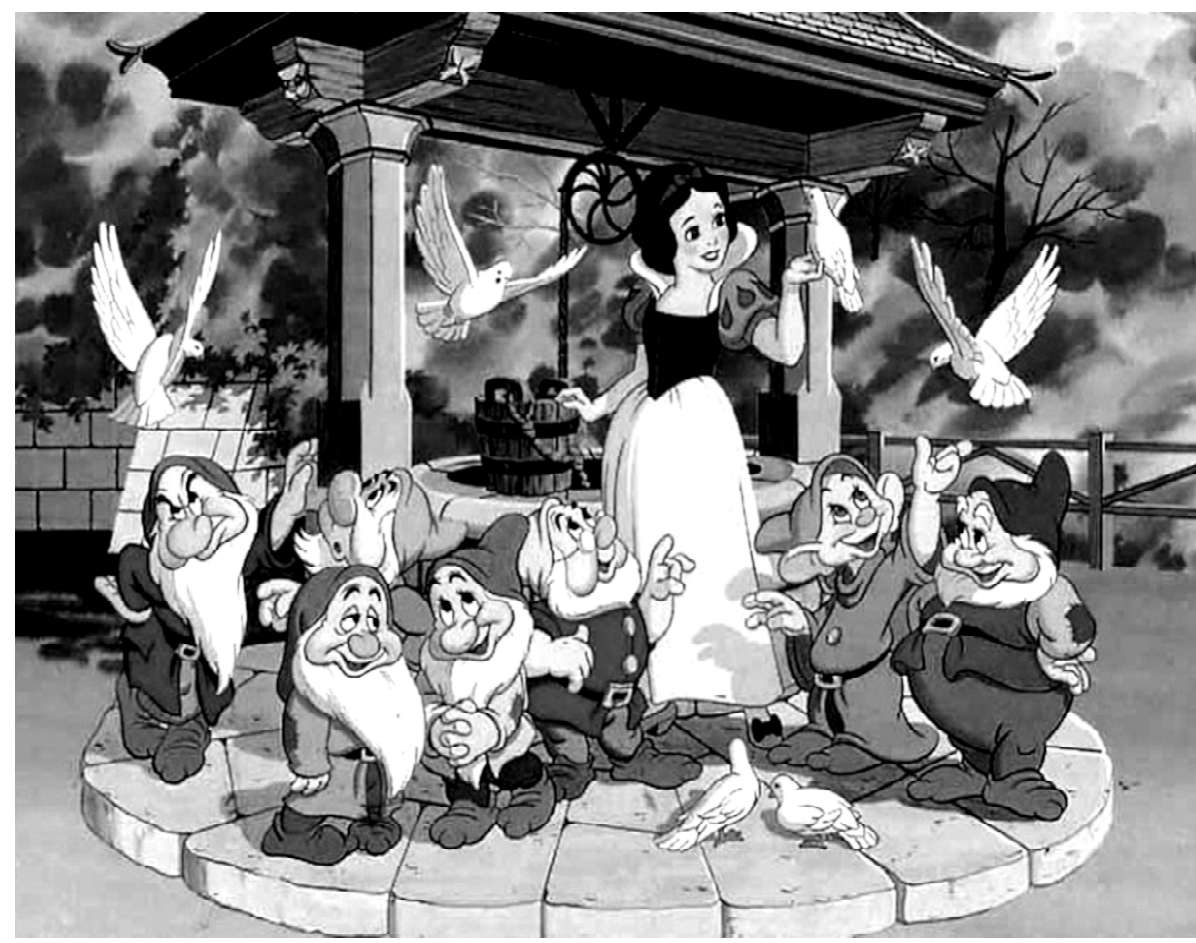

Figura 3

Branca de Neve e os sete anões. 
Como viera a inspiração para a designação do distúrbio? Ela foi inspirada na pintura $O$ garoto com $u m$ fantoche, obra de Gianfrancesco Caroto (1480-1555) que mostra a exagerada gargalhada de uma criança durante a brincadeira com seu fantoche (ANGELMAN, 1965). A "criança fantoche" mantém os cotovelos flexionados durante a marcha, ocorrem espasmos musculares durante o sono e elas exibem caretas e movimentos corporais quando expressam o estado emocional. A síndrome de Angelman é pouco conhecida, mas o cartoon de Disney mostra outros detalhes nas feições de Dunga, como cabeça pouco desenvolvida, nariz e queixo proeminente (prognatismo) e enormes olhos azuis que ressaltam a expressão facial parecida com a de um boneco (DAN \& CHRISTIAENS, 1999). Nos cartoons posteriores os anões ganharam fala e traços de personalidade, mas Dunga continuou mudo e abobalhado.

Os anões que acompanhavam Branca de Neve eram adultos, mas Disney retratou-os como se fossem crianças. $\mathrm{O}$ atraso no desenvolvimento cognitivo sugere outro quadro clínico importante: nanismo psicogênico. Evidências atuais revelam que fatores ambientais (maus tratos, negligência parental e estresse crônico) interferem na produção do hormônio de crescimento (GH, growth hormone), com impacto negativo para o desenvolvimento das estruturas cerebrais. Este hormônio, juntamente com outros produzidos pelo fígado, estimula o crescimento das células do corpo, mas a privação alimentar e o estresse promovem a elevação nos níveis do hormônio cortisol, o qual, por seu turno, interfere negativamente neste mecanismo. $\mathrm{O}$ GH é liberado durante o sono, de modo que perturbações nos ciclos de sono-e-vigília também dificultam o crescimento físico (lembremos que Soneca tinha sonolência diurna, fenômeno comumente relacionado à hipoventilação durante o sono).

Outros personagens da literatura infantil também exibem notável atraso no desenvolvimento físico, como Pequeno Polegar. Ele era filho de um pobre lenhador que vivia numa choupana com a mulher. Os dois desejavam ardentemente um filho, "mesmo que fosse tão pequenino, não maior que o tamanho de um polegar". As dificuldades reprodutivas são evidentes, pois o bebê veio tardiamente e nasceu pequenino, provavelmente em razão de um parto prematuro. A criança não ganhava corpo, mesmo recebendo a sua cota diária de ração, e acabou sendo vendido pelo pai a dois estranhos que se encantaram com seu tamanho - "esse moleque pode nos tornar ricos se o exibirmos de cidade em cidade", cochichava um para o outro. Como informamos anteriormente, essas crianças eram vendidas ou até trocadas por mulas e vacas, pois serviam de entretenimento aos ricos.

A historieta O jovem gigante e o alfaiate (Contos de Grimm, 2002) descreve a vida de um menino que nascera igualmente pequenino, filho de um agricultor. 
Ela é ainda mais elucidativa dos efeitos psicossociais sobre o desenvolvimento infantil. Polegarzinho insistia junto ao pai para ser levado aos campos de trabalho, mas ele corria risco de ser perder até na vegetação rasteira e, portanto, o pedido era sempre recusado. Polegarzinho continua a insistir e o pai acaba cedendo aos seus apelos. A criança se encanta com as novidades e, inesperadamente, surge um gigante que se sente atraído pela minúscula criatura. Ele leva Polegarzinho consigo e o pai, amedrontado, não esboça reação alguma. Os leitores poderiam imaginar que a criança iria passar maus momentos nas mãos do gigante, mas ocorre o contrário: ele trata a criança com muito carinho, divide o alimento e a acalenta no colo. Diante disso, Polegarzinho sofre uma enorme transformação e se torna um gigante tão forte a ponto de não mais ser reconhecido pelo próprio pai.

O nanismo psicogênico também está associado ao atraso no desenvolvimento cognitivo. Caso a criança seja removida de uma situação adversa, ocorre uma aceleração do crescimento, mas a compensação depende da natureza, intensidade e do tempo que ela ficou exposta às adversidades sociais e psicológicas (SONINO \& FAVA, 1998). Os efeitos do estresse crônico sobre o desenvolvimento físico e mental também é conhecido como síndrome de Kaspar Hauser, alusão ao estranho personagem que supostamente fora raptado ainda criança e que exibia deficiência mental e nanismo psicogênico (MONEY, 1994). A historieta descrita acima informa que Polegarzinho exibiu rápido e notável desenvolvimento físico após ter sido tutelado pelo gigante, o que sugere que as causas de seu nanismo se encontravam no próprio ambiente doméstico. Talvez fosse resultante de uma dieta pobre, negligência parental (o conto não menciona a presença materna) e as preocupações do pai com o sustento da família.

\section{Cartoons: Ariel, Pooh e Homer Simpson}

Os cartoons de Walt Disney modificaram o enredo original de algumas historietas, dando-lhes um desfecho "mais aceitável". O conto A pequena sereia (ANDERSEN, 1974) tem um final trágico (Ariel morre abraçada ao amante), mas na versão de Disney eles "vivem felizes para sempre". A preocupação com a mensagem positiva não é uma inovação dos cartoons, pois Perrault e os irmãos Grimm têm versões diferentes para o desfecho da história de Chapeuzinho Vermelho. O primeiro descreve que a vovozinha e a simpática mocinha morrem devoradas pelo lobo mau, sem mais detalhes. A versão dos irmãos Grimm estende o final, pois informa que as duas são resgatadas por um caçador - ele desfere um tiro no animal e abre o seu ventre, permitindo que elas escapem ilesas. O animal perde a consciência e Chapeuzinho Vermelho aproveita a oportunidade para se vingar de suas maldades: ela enche o seu bucho com pedras e a impossibilidade de locomoção o leva à inanição. 
As historietas infantis inspiraram vários cartoons de Walt Disney, mas os enredos foram adaptados de modo a veicularem mensagens positivas ou para se adequarem aos novos tempos. Entretanto, vários personagens fumam charutos e cachimbos ou ingerem bebidas alcoólicas como se estivessem praticando algo trivial (GOLDSTEIN et al., 1999). Muitos desses cartoons são antigos e foram produzidos quando inexistiam preocupações acerca dos malefícios causados pelo tabagismo e alcoolismo. $\mathrm{O}$ assunto deveria ser examinado com mais atenção pelos especialistas, pois esse tipo de entretenimento é quase que exclusivamente direcionado às crianças e muito material antigo ainda é veiculado na nossa TV, embora o conteúdo seja incompatível com os tempos modernos.

Alguns personagens dos cartoons são temperamentais, irrequietos e vingativos, sugerindo que eles padecem de graves distúrbios comportamentais (transtorno do déficit de atenção/hiperatividade, personalidade anti-social e bullying, por exemplo). Algo curioso ocorreu com o Zé Carioca (Joe Carioca, era o nome original), cuja estréia se deu em The three caballeros (1945). Além do título inadequado, que sugere que o seu idioma nativo é o espanhol, o Zé Carioca foi desenvolvido para ilustrar a suposta natureza do brasileiro: mandrião, pouco afeito aos compromissos sociais e sempre interessado em passar alguém para trás. $\mathrm{O}$ malandro sempre trazia um charuto à boca e, numa ocasião, ele induziu o pato Donald a provar a nossa cachaça. Walt Disney (190166) era um fumante inveterado e a sua morte foi atribuída a um câncer pulmonar; muitos de seus cartoons foram produzidos no final da II Guerra Mundial e nessa época não havia uma compreensão clara sobre a conexão entre o tabagismo e alcoolismo e doenças crônicas.

\section{Ariel e a "maldição de Ondina"}

Personagens da mitologia grega serviram de inspiração para epônimos científicos ou expressões eruditas, como "tendão de Aquiles" e "voto de Minerva". Em termos médicos, "maldição de Ondina" é uma forma de hipoventilação ou falha na ventilação autonômica que ocorre durante o sono (apnéia noturna). O fenômeno é ocasionado por vários fatores, como lesões nas vias retículo-espinhais ou disfunção no tronco cerebral (ÖSTÖR \& PHILLIPS, 1999; NANNAPANENI et al., 2005).

Ondinas também são conhecidas como Nereidas, as filhas do deus marinho Nereu, mais antigo que Netuno. Ele era filho do Oceano e de Tétis ou da Terra, de acordo com as diferentes da mitologia grega. Nereu se casara com Dóris, sua irmã, e tivera 50 filhas (nereidas). As filhas comumente são retratadas como belas e alegres donzelas, dotadas de vastas cabeleiras entrelaçadas com pérolas. 


\section{HUMANAS}

As nereidas despendiam a maior parte do tempo divertindo Nereu com danças e cantos; o corpo era metade mulher, metade peixe (abaixo da cintura) e elas se deslocavam pelos mares montadas em delfins ou cavalos-marinhos.

É comum a confusão entre nereidas e sereias, mas elas são criaturas distintas. Sereias são feiticeiras, filhas do Rio Aquelôo e da musa Calíope, que atraem os marinheiros para a morte com a voz doce e melodiosa. Sereias são erroneamente retratadas como mulheres-peixe, mas a "afinidade filogenética" é com os pássaros, pois são criaturas aladas ou são pássaros com busto e cabeça de mulher (ROMANO et al., 2006). Os marinheiros eram seduzidos pela sua voz maravilhosa e logo perdiam a lembrança da pátria e da família; eles morriam de inanição, pois se "esqueciam" de suprir o corpo com água e alimento. As inúmeras lendas descrevem as sereias como criaturas imortais, mas sem alma. As histórias descrevem que uma delas se apaixona por um homem e isto lhe satisfaz o desejo de possuir uma alma humana, mas também lhe subtrai o dom da imortalidade. O amor entre os dois deveria ser mútuo e para sempre, caso contrário a traição resultaria na morte da criatura aquática e de seu consorte.

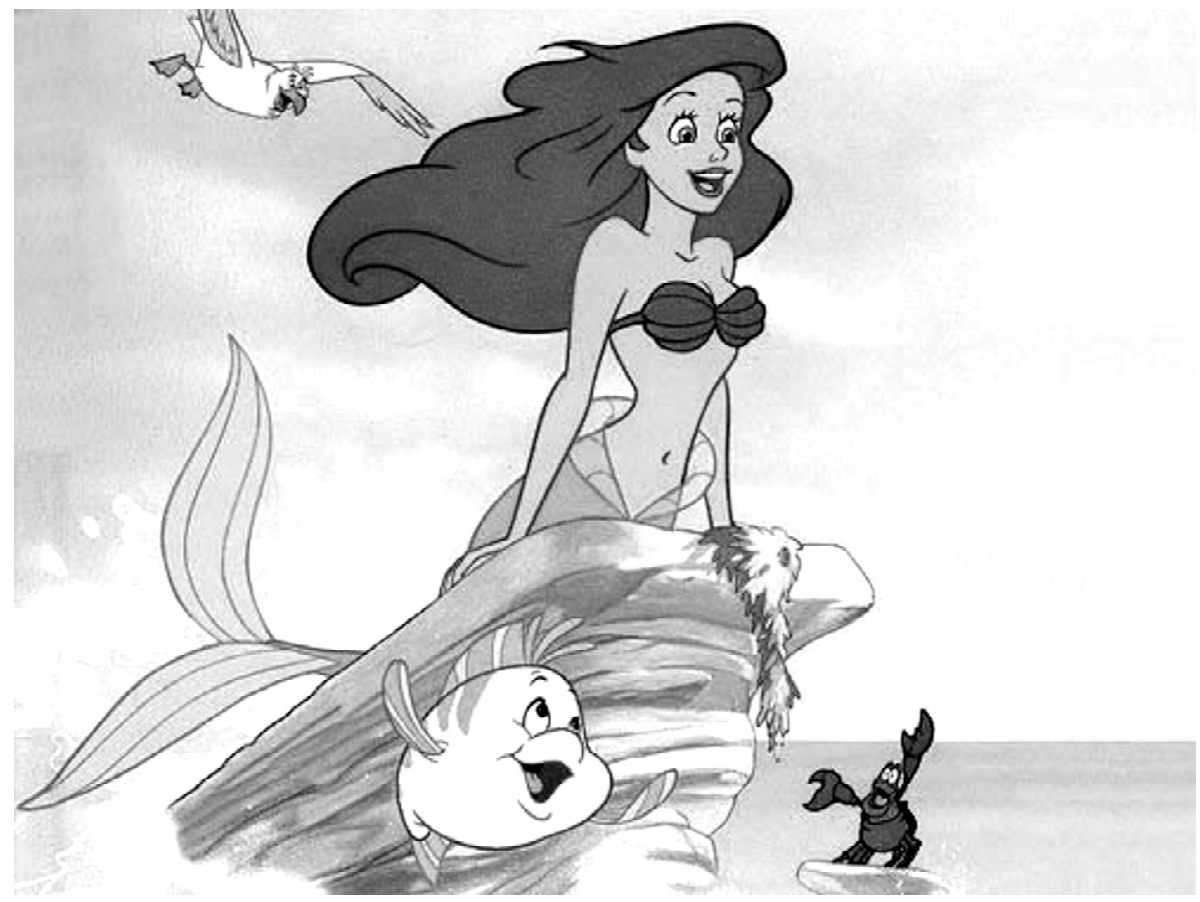

Figura 4

Ariel, a "sereiazinha" apaixonada. 
Homero (c.900AC) descreveu as criaturas que encantavam os marinheiros, as quais eram conhecidas pela beleza e voz sedutora (Odisséia, livro XII). O mito foi consolidado a partir do romance Undine (1811), de Friedrich Heinrich Karl, ou Barão de la Motte-Fouqué (1777-1843), mas a popularização veio com a historieta de H.C. Andersen e o cartoon de Walt Disney. O romance descreve que o amor entre a ondina e o homem era intenso, mas não eterno. A criatura aquática acaba sendo traída pelo amado e isto traz graves conseqüências para ambos. Ela retorna aos seus braços para o adeus final e, ao revelar o destino de ambos, o homem fica completamente desolado e cai num sono profundo quando recebe o beijo de despedida. Ondina morre abraçada ao amado e este acaba se "esquecendo" de respirar (versão de Motte-Fouqué). A historieta de Andersen (A pequena sereia, 1836) é bem diferente, mas igualmente trágica, e alimentou a confusão sobre nereidas e sereias. Ao saber que outra mulher habitava o coração de seu amado, Ariel morre em lenta e dramática agonia e se transforma em "filha do ar" - este final relembra que o mundo das sereias não são as profundezas do mar.

A versão de Hippolyte Jean Giraudoux (1882-1944), escritor e diplomata francês (ele foi ministro da Informação durante a II Guerra Mundial), foi a que mais diretamente inspirou o epônimo "maldição de Ondina". A sua versão do mito das ondinas (Undine, 1939) descreve que a criatura aquática se apaixonara pelo cavaleiro Hans von Wittenstein zur Wittenstein, tendo Bertha como sua rival. $\mathrm{O}$ rei das ondinas descobre a infidelidade de Hans e clama por sua morte, mostrando-se insensível aos apelos de Ondina para que a sua vida fosse preservada. A desafortunada criatura aquática argumenta que todos os casais enfrentam problemas e que o diálogo é a forma mais razoável de resolver as diferenças entre homem e mulher. Os argumentos poderiam ser utilizados numa psicoterapia para casais, mas não foram suficientes para amolecer o coração do rei das ondinas. Sabendo que todas as suas lembranças da vida terrena seriam apagadas logo após a morte do amado, Ondina retorna aos braços de Hans para lhe dar o último adeus, mas este acaba caindo em profundo desalento ao saber o que o futuro the aguarda. Ele perde a motivação para a vida, todo o seu corpo se "recusa" a funcionar: ele se "esquece" de respirar e nada lhe é mais cansativo que mobilizar os músculos para executar funções corporais simples. Ele cai num sono profundo e a vida lhe escapa devido à maldição de Ondina.

As três versões são belas, mas igualmente trágicas. Elas encantam as crianças do mundo inteiro, pois exploram temas universais e atemporais (e.g., amizade, paixões não-correspondidas, infidelidade e morte). A simpática "sereiazinha" (estamos falando de Ariel) desejava a humanidade plena, mesmo que isso significasse a perda da imortalidade. Algo parecido ocorreu com o boneco Pinóquio que, ao final, é transformado pela sua fada madrinha num menino de verdade. 
Quem é capaz de manter-se insensível diante dessa ode ao gênero humano? A fórmula é tão eficaz que foi explorada em recentes sucessos cinematográficos, como Blade runner (1982), Bicentennial man (1999) e AI- Artificial intelligence (2001).

\section{Obesidade, indolência e Mr. Pickwick}

Alguns personagens das histórias infantis exibem perturbações do sono, associadas ao excesso de peso e baixo discernimento cognitivo (IRANZO et al., 2007). Da mesma forma que as crianças tendem a se identificar com a "inocência" dos anões, o comportamento desajeitado dos obesos atrai as atenções. O excesso de peso geralmente resulta em crônica hipoventilação, fenômeno que explica as elevadas taxas de mortalidade precoce em indivíduos obesos. Os sintomas são facilmente detectáveis: sonolência diurna, fadiga, enxaqueca matutina e ronco durante o sono, o qual é resultante das dificuldades na expulsão do ar. Os pacientes também exibem hipertensão pulmonar (cor pulmonale) e problemas cardíacos variados.

O quadro clínico foi designado como síndrome da hipoventilação em obesos (obesity hipoventilation syndrome), mas é mais conhecida como síndrome de Mr. Pickwick (UEMURA et al., 2000; OLSON \& ZWILLICH, 2005). A enfermidade foi descrida em 1956 e teve como referência um personagem homônimo da obra de Charles Dickens (The posthumous papers of the Pickwick Club, 1837). Da mesma forma que Mr. Pickwick, vários personagens da literatura infantil exibem anomalias parecidas, como iremos examinar mais especificamente em relação ao simpático ursinho Pooh e o indolente Homer Simpson.

$\mathrm{O}$ apetite voraz e a circunferência abdominal de Pooh despertaram a atenção dos médicos. O personagem foi criado por Allan Alexander Milne (18821956), cartunista inglês e autor de Winnie-the-Pooh (1926), historieta que ganhou popularidade a partir de uma série de cartoons veiculados na TV. O exame da morfologia e dos hábitos comportamentais de Pooh revelou que ele tinha sérios distúrbios metabólicos, pois exibia polifagia e o peso corporal era muito acima do esperado para a sua estatura. Pooh ostentava uma enorme circunferência abdominal: a medição da cintura $(37 \mathrm{~cm})$ e do quadril do boneco $(38,5 \mathrm{~cm})$ revelaram que a proporção cintura/quadril $(0,96)$ estava acima do necessário para caracterizar a perigosa obesidade abdominal (i.e., 0,9). Uma vez que é impossível a realização de exames laboratoriais para confirmar o diagnóstico de obesidade abdominal, os médicos resolveram examinar os hábitos alimentares do simpático ursinho. O susto foi maior ainda, pois em todos os episódios Pooh tinha fome constante, comia exageradamente e exibia um gosto especial por mel. Os indícios eram claros: diabete mellitus (McCALLUM \& SMITH, 2005). 
Os pais de hoje lutam para que seus filhos tenham uma alimentação saudável e se envolvam em atividades físicas, de modo que a indolência e os péssimos hábitos alimentares do ursinho Pooh não são bons exemplos para as crianças.

Algo ainda mais grave ocorre com Homer Simpson, pois ele exibe sérios distúrbios da personalidade e o seu "prontuário médico" indica que ele é altamente susceptível a doenças cardiovasculares. Trata-se de um personagem criado em 1989 por Matt Groening e as histórias são veiculadas nos cartoons da Fox Network - ele foi incluído na nossa análise devido à conduta bizarra e por que suas histórias foram transportadas para os comic books (histórias em quadrinhos), lidos por adultos e crianças. Os episódios na TV e os inúmeros sites na Internet permitem que saibamos algo sobre a família Simpson, representante da classe média que vive nos subúrbios das cidades dos EUA. Algumas informações são confusas, como aquelas que dizem respeito à idade (alguns episódios informam que Homer tem entre 36 e 40 anos, mas seus documentos "informam" que ele nasceu em 1955 ou 1956) e peso corporal (aproximadamente $120 \mathrm{k}$, mas aparenta ser mais pesado). Além de Homer, a família Simpson é composta por Marge, a esposa, e os filhos Bart, Lisa e Maggie.

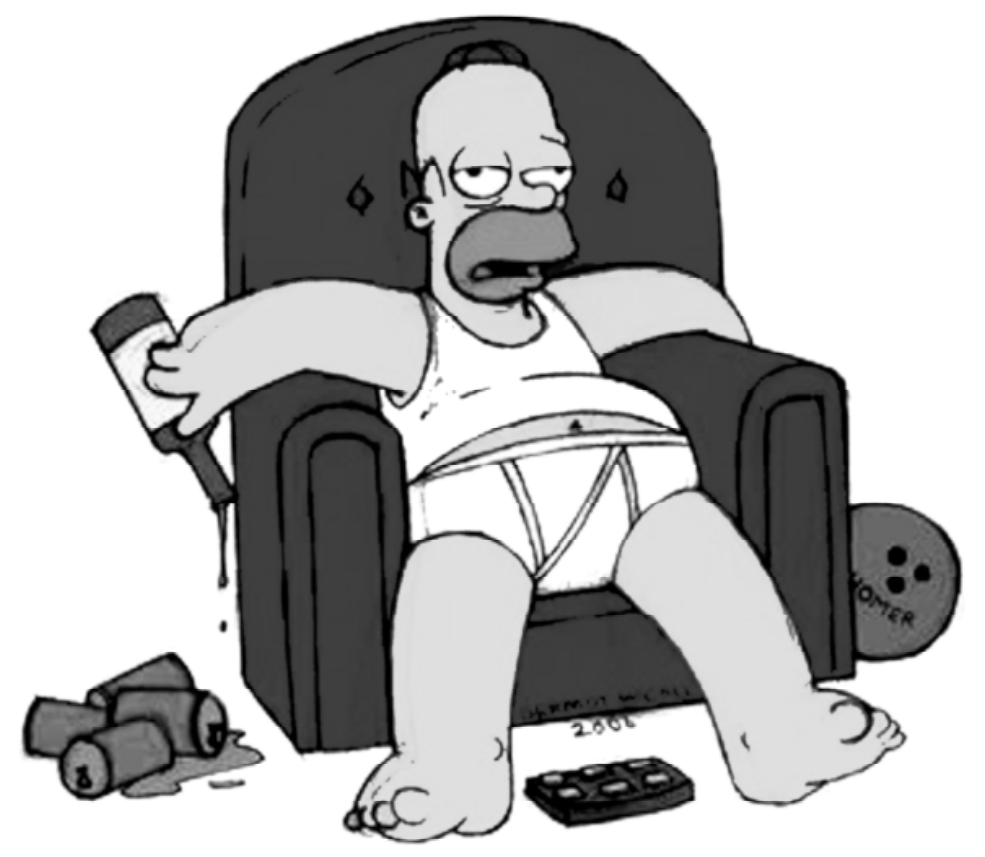

Figura 5

O indolente Homer Simpson, ícone da vida moderna. 


\section{Hümanas}

As informações também revelam que Homer exibe inteligência bem abaixo do normal (QI 55) e que fora vítima de vários acidentes graves. Especialistas do mundo real concordam que é um milagre que ele ainda esteja vivo, pois além de tudo isto ele é um bebedor compulsivo (adora cerveja), exibe enorme apetite e um gosto especial por pizzas e donuts. Ele leva uma vida sedentária e despende todo o tempo disponível cochilando diante da TV (síndrome de Mr. Pickwick). Homer deve ter entre 40 e 50 anos, se levarmos em conta a idade de sua esposa e a de seus dois filhos que ainda se encontram na meninice, mas é indolente e exibe grande flutuação de humor - Bart é a vítima preferencial de sua irritação, pois muitas vezes ele é "estrangulado" pelo pai. O relacionamento familiar é conturbado e os episódios freqüentemente expõem Homer a situações que o deixam com os "nervos à flor da pele". Ele exibe olhos esbugalhados (exoftalmia) e uma calvície quase completa. A obesidade abdominal e a indolência, somados aos efeitos do estresse no ambiente doméstico, tornam Homer Simpson bastante vulnerável a problemas cardiovasculares.

Os episódios não escondem os graves problemas de saúde de seu personagem principal, algo que torna ainda mais pitoresco as histórias. Homer é informado pelo seu médico particular, Dr. Hibbert, que a sua estupidez e indolência são originárias de um fator genético: Simpson stupid gene. O "paciente" se envolvera em acidentes graves e recebera inúmeras pancadas na cabeça (ele fora lutador de boxe), mas uma característica inusitada da morfologia cerebral o protegera das injúrias físicas. Com efeito, exames médicos rotineiros indicaram que Homer tinha uma espessa camada de fluidos que revestia o cérebro, de modo que era como se ele tivesse um capacete dentro da caixa craniana que amortecia as pancadas. Diante disso, o cuidadoso Dr. Hibbert criou um epônimo para designar o fenômeno: "síndrome Homer Simpson". A elucidação do mecanismo causal de uma enfermidade ou a descoberta de um novo fenômeno representa notáveis avanços no conhecimento científico, mas é a primeira vez que uma proeza desse porte ocorre num cartoon!

Outro personagem que despertou as atenções dos médicos é o Papai Noel, destaque na galeria dos párias. Esse tipo de análise tem o seu lado divertido, mas ela é encarada com seriedade pela comunidade médica, pois estamos lidando com modelos comportamentais intimamente relacionados ao universo infantil. Papai Noel exibe graves problemas de saúde, pois ostenta uma descomunal obesidade abdominal, é apreciador de bebidas alcoólicas (brandy ou vinho do porto) e não abre mão de seu cachimbo; além de glutão, ele leva vida sedentária. O bom velhinho maltrata suas renas em busca de maior velocidade, dando a impressão de que ele adora os esportes radicais e não respeita os limites de velocidade-ele nunca usa cinto de segurança e tampouco protege a cabeça com capacete. Uma vez que o ele tem uma atribulada jornada de trabalho na véspera de Natal, 
os habitantes do hemisfério norte (Europa e EUA) colocam guloseimas e uma taça de brandy para que ele recomponha suas energias e possa efetuar as entregas de todos os presentes. O inocente costume - dizem os médicos - fortalece o apego das crianças aos alimentos pouco saudáveis e, mais grave ainda, prejudica as campanhas de prevenção o uso de bebidas alcoólicas por motoristas (ver GRILLS \& HALYDAY, 2009). Não existem estudos que elucidam os efeitos desses modelos comportamentais para a formação da personalidade, mas sem dúvida nenhuma que o Papai Noel é um péssimo exemplo.

\section{O final: "... e viveram felizes para sempre"}

As histórias infantis são repletas de elementos amedrontadores, como bruxas e monstros antropófagos. A cultura brasileira também tem esses monstros, mas eles têm outros nomes: bicho-papão, cuca ou mula-semcabeça; lobos, corujas e cobras são os animais que representam o poder da maldade (GUERRA, 2005). O cenário lúgubre e ameaçador é acentuado com florestas densas, o local preferido para a moradia das bruxas. Os cartoons de TV ilustram as histórias com neblinas densas e vegetação cerrada; sombras simulam a escuridão das noites e os galhos longos das árvores se assemelham a braços e mãos que se armam para capturar os incautos que se atrevem a penetrar nas florestas. O medo dos animais selvagens e os ermos das florestas contrastam com o espírito do homem moderno, o qual vive enclausurado no conforto dos condomínios e se julga um "amante da natureza".

Muitos vêem somente o lado positivo das histórias infantis e recomendam que elas sejam utilizadas como instrumentos em procedimentos psicoterapêuticos (BETTELHEIM, 1975; ROBINSON, 1986; ALEXANDER et al., 2001), mas outros especialistas apontam que os enredos encobrem valores morais anacrônicos e incompatíveis com a vida moderna (TATAR, 1990; WINSTON, 1995; DALY \& WILSON, 1999). Com efeito, mulheres idosas e excêntricas são associadas a bruxaria, da mesma forma que a incapacidade reprodutiva, a feiúra ou deficiência física (corcundas, coxos, cegos ou surdos) indicam caráter malévolo. As historietas também descrevem outras bizarrices, como abandono e comércio de crianças, incestos entre pai e filha, antropofagia, bestialismo e necrofilia. As punições são cruéis e despropositadas e o modus operandi revela certo sadismo, como ocorreu com uma princesa intrigante: ela foi colocada num barril cheio de pregos pontudos, o qual foi arrastado pelas ruas até a morte da pobre coitada (A guardadora de gansos; Contos de Grimm, 2002). 
Esses elementos da cultura popular transmitem valores anacrônicos, mas eles desvendam a antiga estrutura social. As histórias infantis descrevem a servidão e a exploração do trabalho escravo, bem como as diferentes formas de maus-tratos contras as crianças, mulheres e idosos. O despotismo intrafamiliar parece ser uma repetição do poder que os reis e senhores feudais tinham sobre as pessoas que orbitavam a sua influência. Crianças, idosos e, especialmente, as jovens pré-adolescentes são os elementos mais frágeis no mundo das histórias infantis. As mocinhas ansiavam ardentemente por um casamento, pois essa era a forma que elas encontravam para escapar do jugo paterno. Os casamentos eram arranjados, muitas vezes a mocinha sequer sabia quem era o noivo e o noivado era excessivamente curto ou mesmo inexistente. Os enredos são tenebrosos, mas o desfecho quase sempre era temperado com uma mensagem positiva: "... e viveram felizes para sempre". Entretanto, a mensagem final apenas esconde a dura realidade das mulheres, pois a subserviência e o anseio pela vinda de um príncipe encantado são sintomas daquilo que as feministas conhecem como "complexo de Cinderela".

Os limites entre a realidade e o sobrenatural não são bem estabelecidos, pois animais, monstros e criaturas imaginárias interagem com os personagens. As histórias são curtas e repetitivas, sem espaço para descrições acerca das idiossincrasias dos personagens. Tais características facilitam a assimilação dos enredos pela mente infantil. Outra característica deve ser enfatizada: as histórias infantis pertencem ao rico acervo das tradições orais e, portanto, eram relatadas pelas mães ou algum adulto familiar às crianças. No momento em que a família se recolhia para o repouso noturno, as histórias eram relatadas num ambiente pouco iluminado. Enlaçada pelos braços maternos e saboreando uma doce exclusividade, a criança mergulhava num devaneio pré-onírico. Os enredos envolviam bruxas malévolas e monstros devoradores de crianças, mas ela logo percebia quem eram seus verdadeiros protetores. $\mathrm{O}$ agasalho espiritual fornecia um contraste com os perigos da vida real, de modo que os enredos exagerados e fantasiosos contribuíam para o fortalecimento do vínculo da criança com os pais.

\section{Referências bibliográficas}

AGGRAWAL, A. References to the paraphilias and sexual crimes in the Bible. Journal of Forensic and Legal Medicine, 16(33): 109-14, 2009.

ALEXANDER, K.J; MILLER, P.J. \& HENGST, J.A. Young children's emotional attachments to stories. Social Development, 10(3): 374-98, 2001.

ANDERSEN, H.C. The complete fairy tales \& stories. New York: Doubleday \& Co., 1974. 
ANGELMAN, H. "Puppet" children: a report on three cases. Developmental Medicine and Child Neurology, 7: 681-88, 1965.

BETTELHEIM, B. The uses of enchantment: the meaning and importance of fairy tales. Nova York: Knopf, 1975.

BIRAN, I. \& STEINER, I. The speech disorder of Doc in Walt Disney's "Snow White and the Seven Dwarfs". Neurology, 57: 363, 2001.

BOKEY, K. \& WALTER, G. Literature and psychiatry: the case for a close liaison. Australasian Psychiatry, 10(4): 393-99, 2002.

BRAGA, T. O povo português nos seus costumes, crenças e tradições. Lisboa: Publicações Dom Quixote, 1995.

BRAGA, T. Contos tradicionais do povo português. Lisboa: Publicações Dom Quixote, 2002.

CAMPBELL, C. \& LEE, J.Z. A death in the family: household structure and mortality in rural Liaoning: life-event and time-series analysis, 1792-1867. The History of the Family, 1(3): 297-328, 1996.

CASCUDO, L. da C. Dicionário do folclore brasileiro. Belo Horizonte e São Paulo: Editora Itatiaia e EDUSP, 1988.

CASCUDO, L. da C. Contos tradicionais do Brasil. Rio de Janeiro: Ediouro, 1999.

CHRISTOPOULOS, S.; SZILAGYI, A. \& KAHN S.R. Saint-Anthony fire. The Lancet, 358 (November 17): 1694, 2001.

COELHO, A. Contos populares portugueses. Lisboa: Ulmeiro, 1999.

COLLODI, C. As aventuras de Pinóquio. São Paulo: Martin Claret, 2002.

CONTOS DE GRIMM. Volumes 1 e 2. Porto Alegre: LPM Pocket, 2002.

DALY, M. \& WILSON, M. The truth about Cinderella. Nova York: Yale University Press, 1999.

DAN, B. \& CHRISTIAENS, F. Dopey's seizure. Seizure, 8: 238-40, 1999.

De CAMPOS, A. Antologia portuguesa - Trancoso: Histórias de proveito e exemplo. Lisboa: Livraria Ailland \& Bertrand, 1921.

De COSTA. C. St. Anthony's fire and living ligatures: a short history of ergometrine. The Lancet, 359 (May 18): 1768-70, 2002. 


\section{HUMANAS}

Do REGO, J.L. Menino de engenho. Rio de Janeiro: José Olympio Editora, 2003. DOSTOYEVSKY, F. Noites brancas e outras histórias. São Paulo: M.Claret, 2007. FREYRE, G. Casa-grande \& senzala. Rio de Janeiro: Editora Record, 1999. FÜRSTENHEIM, E.G. Märchen and fairy tales. German Life and Letters, 4(3): 162-70, 1951.

GOLDSTEIN, A.O.; SOBEL, R.A. \& NEWMAN, G.R. Tobacco and alcohol use in G-Rated children's animated films. JAMA, 281(12): 1131-36, 1999.

GRILLS, N.J. \& HALYDAY, B. Santa Claus: a public pariah? British Medical Journal, 339 (December 19): 5261, 2009.

GRIMM'S FAIRY TALES. Londres: The Folio Society Ltd., 1996.

GUERRA, R.F. Sereias, lobisomens e animais no imaginário. Humanidades/ UnB, 51(Maio): 61-82, 2005.

HAWORTH, J.C. \& CHUDLEY, A.E. Dwarfs in art. Clinical Genetics, 59(2): $84-87,2001$.

HORSLER, K. \& OLIVER, C. The behavioural phenotype of Angelman syndrome. Journal of Intellectual Disability Research, 50(1): 33-53, 2006.

IRANZO, A.; SCHENCK, C.H. \& FONTE, J. REM sleep behavior disorder and other sleep disturbances in Disney animated films. Sleep Medicine, 8(5): 331-36, 2007.

McCALLUM, B.J. \& SMITH, S.M. Ailing allegories and sickly stories: the quest for pathology in children's literature. The Medical Journal of Australia, 183(11/12): 670-71, 2005.

MONEY, J. The Kaspar Hauser syndrome of "psychosocial dwarfism". Buffalo: Prometheus Books, 1994.

NANNAPENENI, R.; BEHARI, S.; TODD, N.V. \& MENDELOW, A.D. Retracing “Ondine's curse”. Neurosurgery, 57(2): 354-64, 2005.

OLSON, A.L. \& ZWILLICH, C. The obesity hypoventilation syndrome. The American Journal of Medicine, 118: 948-56, 2005.

ÖSTÖR, A.G. \& PHILLIPS, G.E. Immortal women: essays in medical eponyms: part I. The American Journal of Surgical Pathology, 23(5): 495-501, 1999. 
ROBINSON, J.G. Fairy-tales and teaching family therapy. Journal of Family Therapy, 8: 383-93, 1986.

ROMANO, S.; ESPOSITO, V.; FONDA, C.; RUSSO, A. \& GRASSI, R. Beyond the myth: the mermaid syndrome from Homerus to Andersen. European Journal of Radiology, 58: 252-59, 2006.

ROMERO, S. Contos populares do Brasil. São Paulo: Landy Editora, 2000.

ROSENFIELD, D.B. Do stutterers have different brains? Neurology, 57: 171-72, 2001.

ROTHENBERG, M.B. The dying child. In: J.D. Noshpitz (Editor-in-Chief). Basic handbook of child psychiatry. Pp. 477-82. Nova York: Basic Books, 1979.

SEDNEY, M.A. Maintaining connections in children's grief narratives in popular film. American Journal of Orthopsychiatry, 72(2): 279-88, 2002.

SIMPSON, D. Phrenology and the neurosciences: contributions of F.J. Gall and J.G. Spurzheim. Australian and New Zealand Journal of Surgery, 75: 475-82, 2005.

SONINO, N. \& FAVA, G.A. Psychosocial aspects of endocrine disease. Clinical Endocrinology, 49: 1-7, 1998.

STONE, J.L. Mark Twain on phrenology. Neurosurgery, 53(6): 1414-17, 2003.

TATAR, M. The hard facts of the Grimm's fairy tales. Princeton: Princeton University Press, 1990.

TOOLEY, G.A.; KARAKIS, M.; STOKES, M. \& OZANNE-SMITH, J. Generalizing the Cinderella effect to unintentional childhood fatalities. Evolution and Human Behavior, 27: 224-30, 2006.

UEMURA, K.; HARADA, K.; SHIOTANI, A.; KAI, A.; URATA, Y.; YASUHARA, M. \& YOSHIDA, K. Obesity-sleep apnea (Pickwickian) syndrome: autopsy findings and a medicolegal review. Legal Medicine, 2: 36-41, 2000.

WALLER, J. A forgotten plague: making sense of dancing mania. The Lancet, 373 (February 21): 624-5, 2009.

WINSTON, J. Careful the tale you tell - fairy tales, drama and moral education. Children \& Society, 9(4): 80-93, 1995. 